1995

\title{
An Analysis of Wetland Total Phosphorus Retention and Watershed Structure
}

Megan K. Greiner

College of William and Mary - Virginia Institute of Marine Science

Follow this and additional works at: https://scholarworks.wm.edu/etd

Part of the Hydrology Commons, and the Water Resource Management Commons

\section{Recommended Citation}

Greiner, Megan K., "An Analysis of Wetland Total Phosphorus Retention and Watershed Structure" (1995). Dissertations, Theses, and Masters Projects. Paper 1539617694.

https://dx.doi.org/doi:10.25773/v5-3xv1-5r47

This Thesis is brought to you for free and open access by the Theses, Dissertations, \& Master Projects at W\&M ScholarWorks. It has been accepted for inclusion in Dissertations, Theses, and Masters Projects by an authorized administrator of W\&M ScholarWorks. For more information, please contact scholarworks@wm.edu. 
Archives

rims

Thesis

Grenier

c. 2

\section{AN ANALYSIS OF WETLAND TOTAL PHOSPHORUS}

RETENTION AND WATERSHED STRUCTURE

\section{A Thesis}

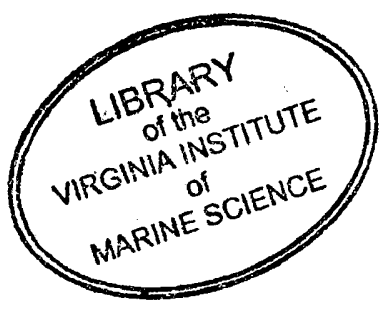

Presented to

The Faculty of the School of Marine Science,

The Coilege of William and Mary in Virginia

In Partial Fulfillment

Of the Requirements for the Degree of

Master of Arts

by

Megan K. Greiner

1995 
APPROVAL SHEET

This thesis is submitted in partial fulfillment of the requirements for the degree of

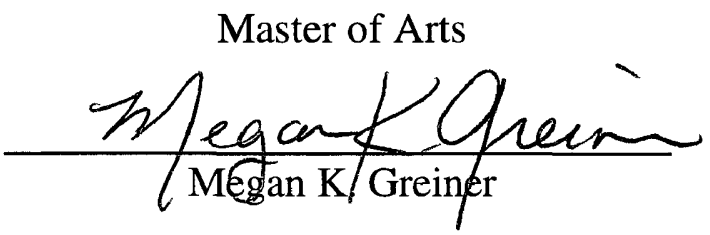

Approved, March 29, 1995

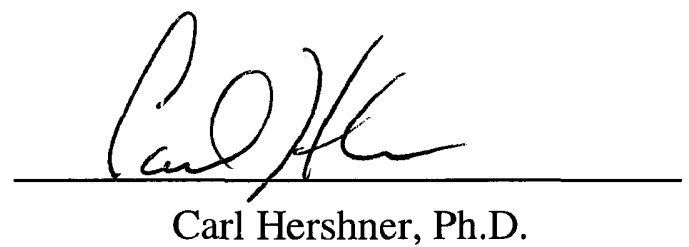

Committee Chairman/Advisor
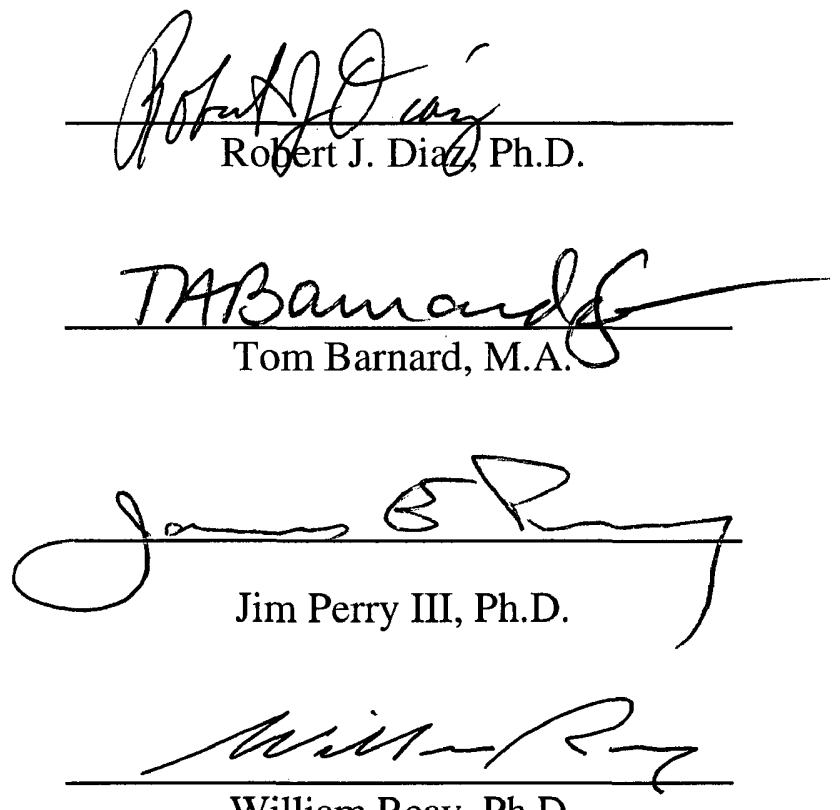

William Reay, Ph.D. 


\section{TABLE OF CONTENTS}

LIST OF TABLES. $\ldots \ldots \ldots \ldots \ldots \ldots \ldots \ldots \ldots \ldots \ldots \ldots \ldots \ldots \ldots \ldots$

LIST OF FIGURES. $\ldots \ldots \ldots \ldots \ldots \ldots \ldots \ldots \ldots \ldots \ldots \ldots \ldots \ldots \ldots \ldots \ldots$

ACKNOWLEDGEMENTS. . . . . . . . . . . . . . . . . . . . .

ABSTRACT $\ldots \ldots \ldots \ldots \ldots \ldots \ldots \ldots \ldots \ldots \ldots \ldots \ldots \ldots \ldots \ldots \ldots \ldots$ iv

1.0 GENERAL INTRODUCTION $\ldots \ldots \ldots \ldots \ldots \ldots \ldots \ldots \ldots \ldots \ldots \ldots \ldots \ldots \ldots \ldots$

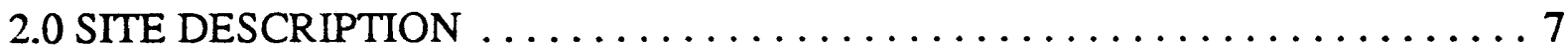

3.0 Total phosphorus retention and sediment accumulation in coastal Virginia wetlands 11

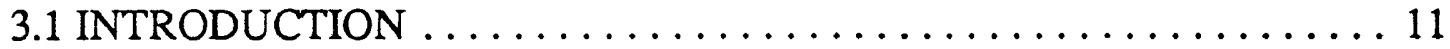

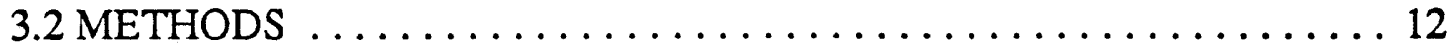

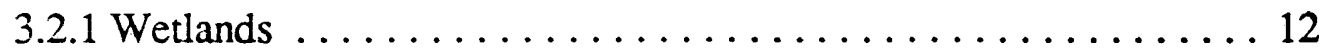

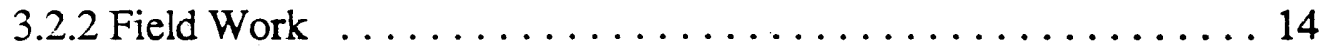

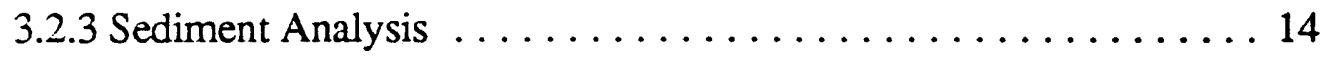

3.2.4 Statistical Analysis . . . . . . . . . . . . . . . . . 16

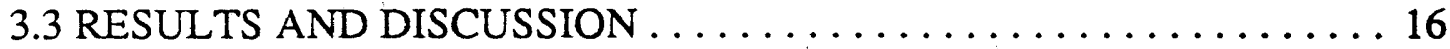

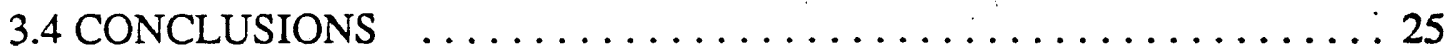

4.0 Watershed analysis of wetland total phosphorus retention using Geographic

Information Systems. . . . . . . . . . . . . . . . . . . . 28

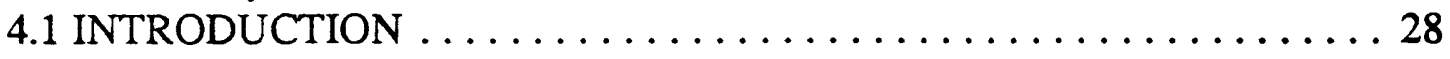

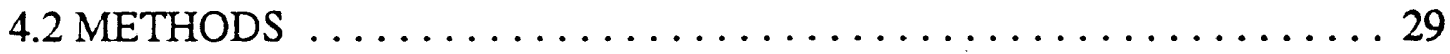

4.2.1 Watershed Characterization ................... 29

4.2.2 Watershed Analysis . . . . . . . . . . . . . . . . 31

4.2.3 Cumulative Watershed Analysis ................. 32

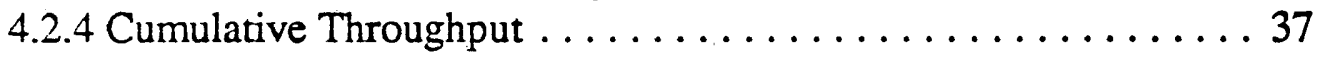

4.3 RESULTS AND DISCUSSION $\ldots \ldots \ldots \ldots \ldots \ldots \ldots \ldots \ldots \ldots \ldots \ldots \ldots$

4.3.1 Watershed Analysis ........................... 37

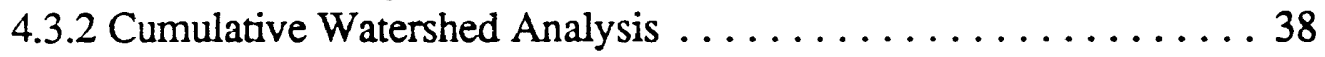

4.3.3 Cumulative Throughput $\ldots \ldots \ldots \ldots \ldots \ldots \ldots \ldots \ldots$

4.4 CONCLUSIONS/IMPLICATIONS FOR WATERSHED MANAGEMENT 43

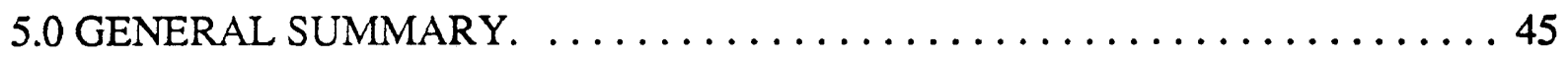

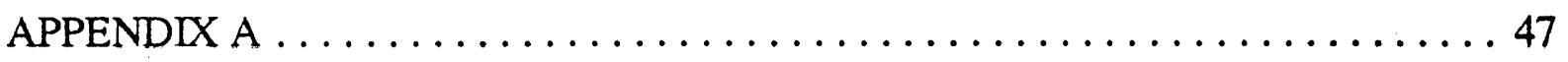

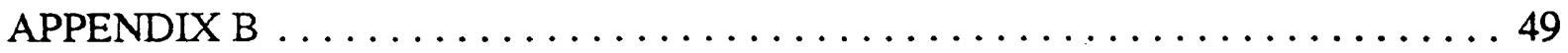




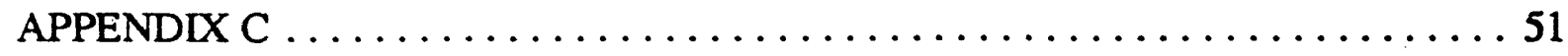

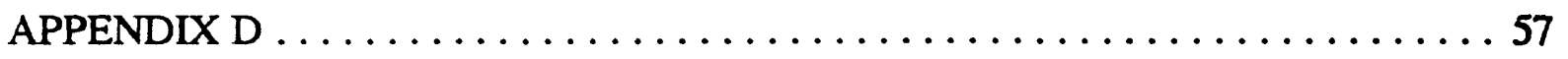

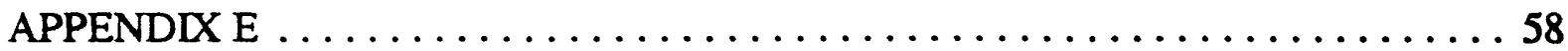

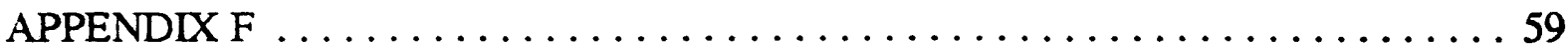

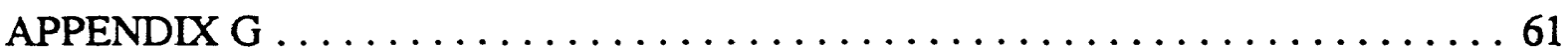

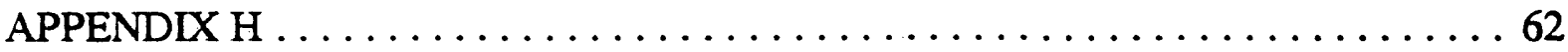

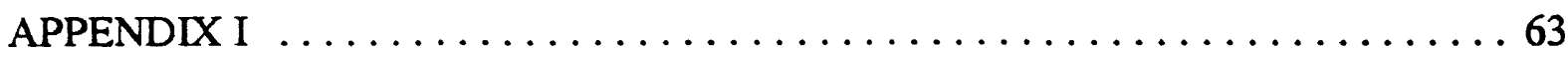

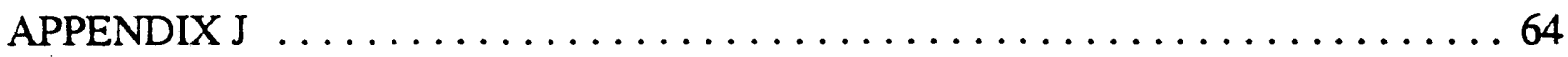

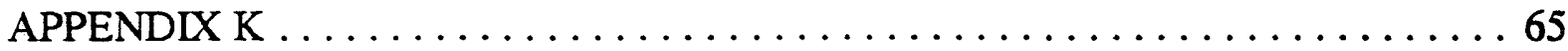

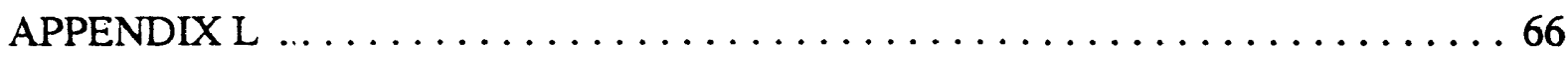

LITERATURE CITED $\ldots \ldots \ldots \ldots \ldots \ldots \ldots \ldots \ldots \ldots \ldots \ldots \ldots \ldots \ldots \ldots \ldots \ldots \ldots$ 


\section{LIST OF TABLES}

Table 1 Summary of wetland total phosphorus retention rates. . . . . . . . 13

Table 2 Summary of wetland sediment accumulation rates $\ldots \ldots \ldots \ldots \ldots 19$

Table 3 Wetland burial and loss indicators for sampled wetland sites. . . . . 20

Table $4 \quad$ Wetland burial and loss indicators, summarized by wetland type $\ldots \ldots .21$

Table 5 Wetland burial and loss indicators, summarized by stream order

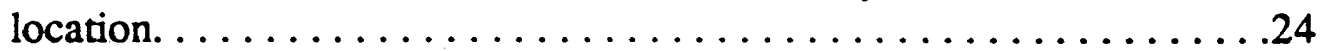

Table 6 Mean percentage of grain sizes for each sediment core $\ldots \ldots \ldots \ldots 26$

Table 7 Literature review of annual non-point loading factors for total

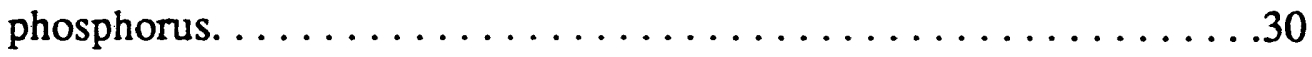

Table 8 Summary of land use areas for Corbin Creek Pond watershed under current conditions, and with simulated development............35

Table $9 \quad$ Results of the principal component analysis . . . . . . . . . . 39

Table 10 Sampled wetlands estimated watershed contributions to total phosphorus retention. . . . . . . . . . . . . . . . . . 


\section{LIST OF FIGURES}

Figure $1 \quad$ Location of study area and wetland sites sampled............9

Figure 2 Land use distribution in watersheds of interest $\ldots \ldots \ldots \ldots \ldots \ldots$

Figure $3 \quad{ }^{137} \mathrm{Cs}$ profiles with depth...................

Figure 4 Total phosphorus concentration profiles with depth.......... 23

Figure 5 Schematic of Corbin Creek Pond watershed "zones" used for study. ... 33

Figure 6 Cumulative watershed throughput, by zone, for Corbin Creek Pond . . .42 


\section{ACKNOWLEDGEMENTS}

Special thanks to my advisor, Dr. Carl Hershner for all of his guidance, support and sense of humor throughout this study. Also thanks to Dr. Bob Diaz for assistance with lab techniques and statistical advice. I gratefully aknowledge and thank Tom Barnard, Jim Perry and Willie Reay for their helpful criticisms, comments and suggestions that helped keep me on track.

Thanks also goes to the various people that provided me with space and helped with work in their labs. This includes Randy Cutter with help learning the isotope dating, and with the tireless task of keeping "the machine" running. Betty Salley and the others in the Nutrient Analysis Lab (Grace, Linda, Ed) for giving me space and teaching me the proper techniques. Trish Tiedemann for showing me what geologists do with their sediment samples.

A special thanks also to the various other individuals that helped me; Jodi Lineberry for help with numerous tasks including sediment analysis, field work, and much appreciated GIS help! Dan Redgate for field help. Dave Fugate for various numerical and statistical advice. Julie Glover for always being willing to come in after hours when the computer wouldn't cooperate with me. Lastly, to all the students in the computer lab that always seemed able to tell why my programs weren't working.

Last but not least, I would like to express my gratitude to all the "trailer" and wetlands folks who provided me not only with valuable computer help but also with much encouragement, support and friendship throughout my time at VIMS. Thanks guys!

Finally, thanks to my family for their encouragement and support! 


\begin{abstract}
A watershed level approach, using Geographic Information Systems (GIS), was employed to explore relationships between wetland total phosphorus retention, wetland position and watershed structure. The objectives of this study were; 1 ) to determine and characterize total phosphorus retention for fourteen wetland sites; 2) to describe land use distributions surrounding the wetland sites; and 3) to explore potential relationships between wetland total phosphorus retention functioning, wetland positioning and cumulative watershed total phosphorus retention functioning. The results showed that oligohaline wetlands in coastal Virginia accumulate sediment $(3.0-5.6 \mathrm{~mm} / \mathrm{yr})$ and retain total phosphorus $\left(0.05-1.30 \mathrm{~g} \mathrm{TP} / \mathrm{m}^{2} / \mathrm{yr}\right)$. Total phosphorus retention can not be predicted by wetland type. Total phosphorus concentrations were found to be correlated with clay $(p<0.001)$ and wetland location as defined by stream order $(p<0.005)$. Watershed total phosphorus throughput was found to vary greatly with different watershed structures. The position of wetlands, and location of development within a watershed could significantly alter water quality within the watershed. Thus, development in the lower reaches of watershed may be the best option. Wetland management should not be based on wetland type, but should consider watershed structure and surrounding land uses. Watershed water quality may be best protected by strategically placing wetlands immediately downstream from any land use with significant phosphorus run off.
\end{abstract}


AN ANALYSIS OF WETLAND TOTAL PHOSPHORUS

RETENTION AND WATERSHED STRUCTURE 


\subsection{GENERAL INTRODUCTION}

Wetlands are both numerous and diverse and exist as one of the most prevalent landscape features throughout the world. With the recognition of the importance of wetlands in their role as ecotones for terrestrial and aquatic systems, understanding the contribution of wetlands to water quality maintenance has become of utmost importance. The Chesapeake Bay watershed contains numerous freshwater and non-tidal wetlands whose role in nutrient retention may be of particular economic and environmental importance. While much research has centered around describing the nutrient budgets of tidal wetlands in this region, only a limited amount has focussed on non-tidal or freshwater wetlands. Furthermore, the majority of wetland nutrient research has focussed on nitrogen budgets, sediment characteristics, hydrology and plant community impacts (ie. Richardson 1985; Walker 1987), and failed to identify or describe the role of other nutrients or pollutants in any great detail.

In freshwater environments, phosphorus is often studied as its fate is thought to be representative of a wider range of nutrients and pollutants (Schueler et al. 1987). It is used by the Washington Council of Governments as a "representative pollutant" (Schueler et al. 1987). Phosphorus occurs as soluble and insoluble complexes in both organic and inorganic forms. Furthermore, it is an analog for most urban pollutants; existing almost equally in both particulate and soluble phases (Mitsch \& Gosselink 1993). While phosphorus does not necessarily present a direct threat to human health, it impacts water systems as excess phosphorus supports eutrophication of surface waters. 
Phosphorus removal in wetlands occurs through vegetative uptake, sediment adsorption and precipitation. In general, phosphorus is relatively unavailable to plants for several reasons: (1) the binding of phosphorus in organic matter, (2) the adsorption of phosphorus to clay particles, organic peat, ferric and aluminum hydroxides and oxides; and (3) the precipitation of insoluble phosphorus which is maximized in soils high in ferric iron, calcium and aluminum (Reed et al. 1989; Mitsch \& Gosselink 1993). For many wetlands, the sorption of phosphorus onto clay particles is particularly important as a large portion of phosphorus input to wetlands is through sedimentation processes. This clayphosphorus complex is believed to result from both the chemical bonding of the phosphates to the clay, as well as the substitution of phosphates for silicate in the clay matrix (Mitsch et al. 1993). Thus, finer textured, clayey soils have the greatest potential for phosphorus sorption while coarse, organic or acidic soils have a low capacity. Soils with significant clay, iron and aluminum are considered good for phosphorus retention. One approach to evaluating and quantifying phosphorus retention in wetlands involves analyzing wetland sediment characteristics (Nichols 1983; Richardson 1985). These studies attempt to explain phosphorus retention by correlation to soil characteristics such as grain size, organics or the presence of aluminum or iron.

Another method of quantifying phosphorus retention capacity of wetlands is common in studies evaluating the use of wetlands as natural wastewater treatment systems. These studies calculate the percent removal of phosphorus from wastewater applied to a wetland system (Nichols 1983; Tilton \& Kadlec 1979) based on measured phosphorus inputs and outputs. However, results are extremely variable ranging from a 
$3 \%$ removal to $98 \%$ removal. Still, a wetland's potential value as a natural wastewater treatment system is of great management value and study interest (Tilton \& Kadlec 1979; Spangler et al. 1977).

The ability of specific wetlands to retain phosphorus may be determined by a combination of internal characteristics including sediment characteristics and hydrology, and the opportunity offered by the load of phosphorus in upland surface water run-off.

Understanding the relationships of land use and wetland positioning to wetland nutrient retention is of significant importance in evaluating the water quality role of wetlands. A number of different pathways exist for nutrient inputs into wetlands. However, several studies have concluded that surface water flow is the dominant phosphorus wetland input (Peterjohn et al. 1984; Correll 1977). Appendix A discusses other possible pathways of nutrient inputs. Phosphorus loadings in run-off can be predicted in watersheds based on the dominant land use present (Rast et al. 1983; Mackiernan 1985; Jones \& Holmes 1985). Thus, loading to a specific wetland is primarily determined by the wetland's position within the watershed and the surrounding upland land uses.

Within a watershed, landscape components can act as sources, sinks, or transformers for nutrient, sediment, and pollutant loads (Detenbeck et al. 1993). Furthermore, other landscape components may significantly influence the transport and redistribution of materials in the watershed. Questions related to the redistribution of materials such as nutrients and sediments are explored in the study of landscape ecology (Turner 1990). 
Landscape ecology seeks to understand the interactions between ecological processes and pattern. It hypothesizes that the spatial arrangement of ecosystems, habitats or communities has ecological implications. Landscape level studies focus on the effect of differences in the landscape mosaic on the fluxes and redistribution of energy, materials and species (Risser 1987; Wiens \& Milne 1989; Golley 1986). Understanding the effects of landscape pattern on ecological processes as well as identifying measures of landscape pattern related to ecological function will provide a valuable tool for future ecological research, management and resource planning (Turner 1990).

Geographic Information Systems (GIS) work with spatial data and are very useful for addressing landscape oriented questions. GIS allows for multiple layers of data to be analyzed quickly. These data layers may involve land uses, vegetation types, topography or pollutant concentrations. The spatial arrangement of ecosystems, habitats or communities is easily extrapolated from data and comparisons between different landscape mosaics may easily be made. GIS is especially useful for the analysis of questions proposed by landscape ecology.

This study combines wetland total phosphorus retention analysis with Geographic Information Systems (GIS) technology in order to address a landscape ecology oriented question testing the hypothesis that wetland total phosphorus retention is related to surrounding land use and wetland position in the landscape.

Sediment accumulation, total phosphorus retention and sediment grain size distributions in fourteen wetland sites near West Point, VA were calculated and compared. Wetland sediment accumulation rates were estimated using ${ }^{137} \mathrm{Cs}$ methods. (Appendix C 
provides some background information on ${ }^{137} \mathrm{Cs}$ methods.) GIS analysis of land use information obtained from satellite imagery combined with calculated total phosphorus retention rates was used to explore the relationship of land use pattern to the phosphorus retention capabilities of wetlands.

In addressing the research hypothesis, this project:

1) calculated sediment accretion rates in the study area wetlands using radioisotope dating;

2) constructed and described total phosphorous profiles with depth using nutrient analysis techniques, and calculated wetland total phosphorus retention and loss rates;

3) collected information describing the wetlands and the watersheds of interest; mapped this information using Geographic Information Systems (Arc/Info, ERDAS) for later analysis;

4) explored potential relationships between wetland variables and total phosphorus retention/loss functioning as well as relationships between wetland positioning and cumulative watershed total phosphorus retention/loss functioning;

5) compared estimated watershed phosphorus budget to measured water quality data. 


\subsection{SITE DESCRIPTION}

The study area consists of three sub-watersheds located on the Mattaponi River near West Point, VA (Figure 1). The Mattaponi is a major tributary of the York River and the reach of the river included in this study is characterized by tidal oligohaline waters. The sub-watersheds are located in the coastal plain of Virginia and are characterized by surficial sandy soils and minimal slopes.

The first watershed consists of West Point Creek which winds through the town of West Point, Virginia. This watershed includes the town of West Point and a large paper mill owned by Chesapeake Corporation. Some small scale agriculture still exists within the watershed, and forested lands are interspersed among the residential developments. The area is dominated by estuarine wetlands. The majority of the wetlands are located on West Point Creek, which runs through the center of West Point. The remaining wetlands are located on the edge of the Mattaponi and York Rivers and act as a buffer between the town and the rivers.

The second and third watersheds include Corbin Creek Pond and Burnt Mill Creek which are located across the Mattaponi from West Point and are dominated by agriculture and forest land uses. These watersheds have seen little development over the last thirty years and remain very rural with occasional buildings and groupings of houses and churches interspersed among croplands and forests. Some timber harvesting has occurred recently in the upper reaches of the Corbin Creek watershed.

Both watersheds are dominated by palustrine forested wetlands. The lower reaches of the watersheds, along the Mattaponi River, consist of estuarine emergent 
wetlands. Land use of the study watersheds is shown in Figure 2 and consists of approximately $3.3 \%$ developed, $10.6 \%$ agriculture, $9.6 \%$ pasture, $61.3 \%$ forested and $15.2 \%$ wetlands. 
Figure 1a. Location and map of study area, including locations of the fourteen sampled wetland sites near West Point, Va.

1b. Plate 1

1c. Plate 2 


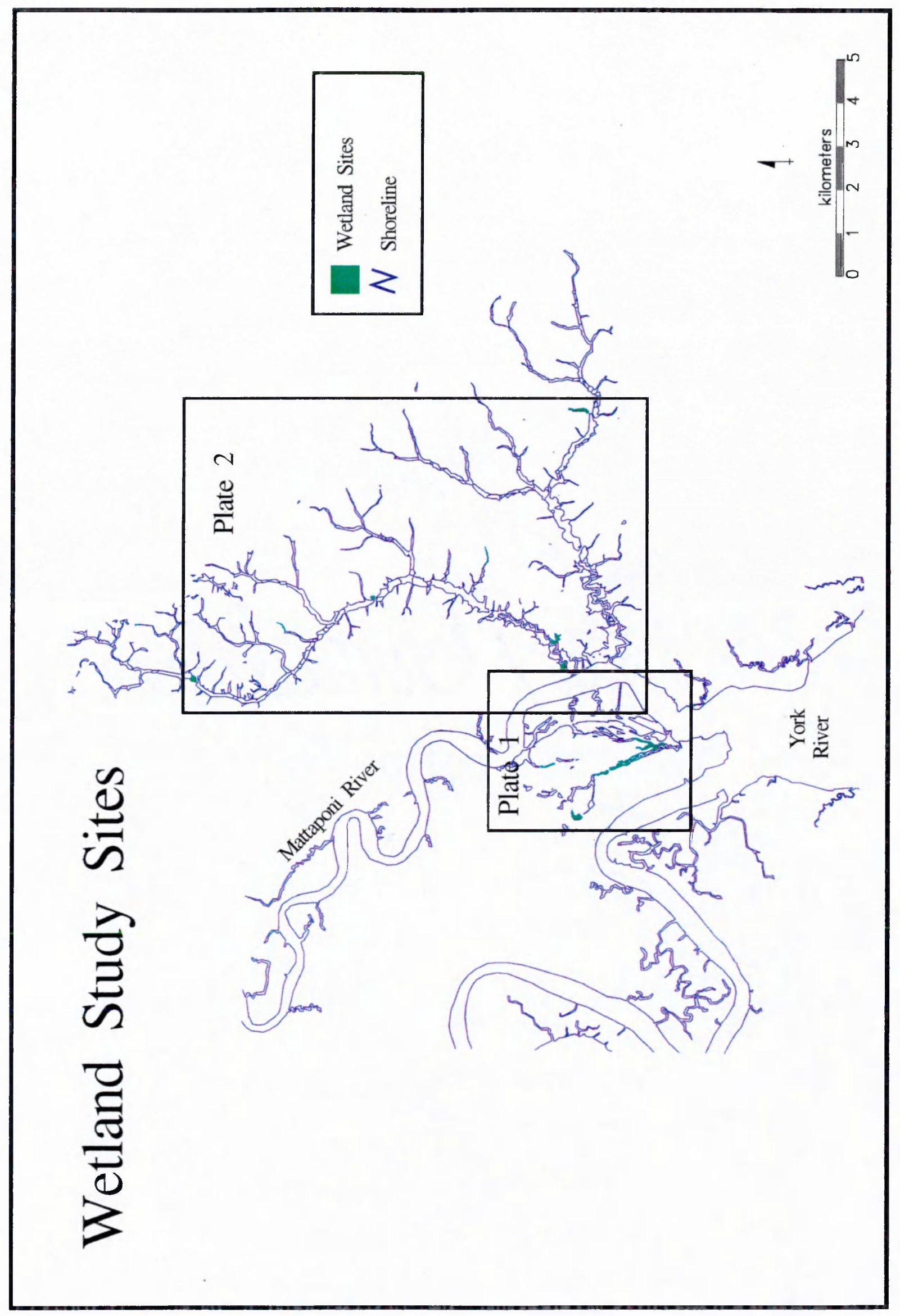




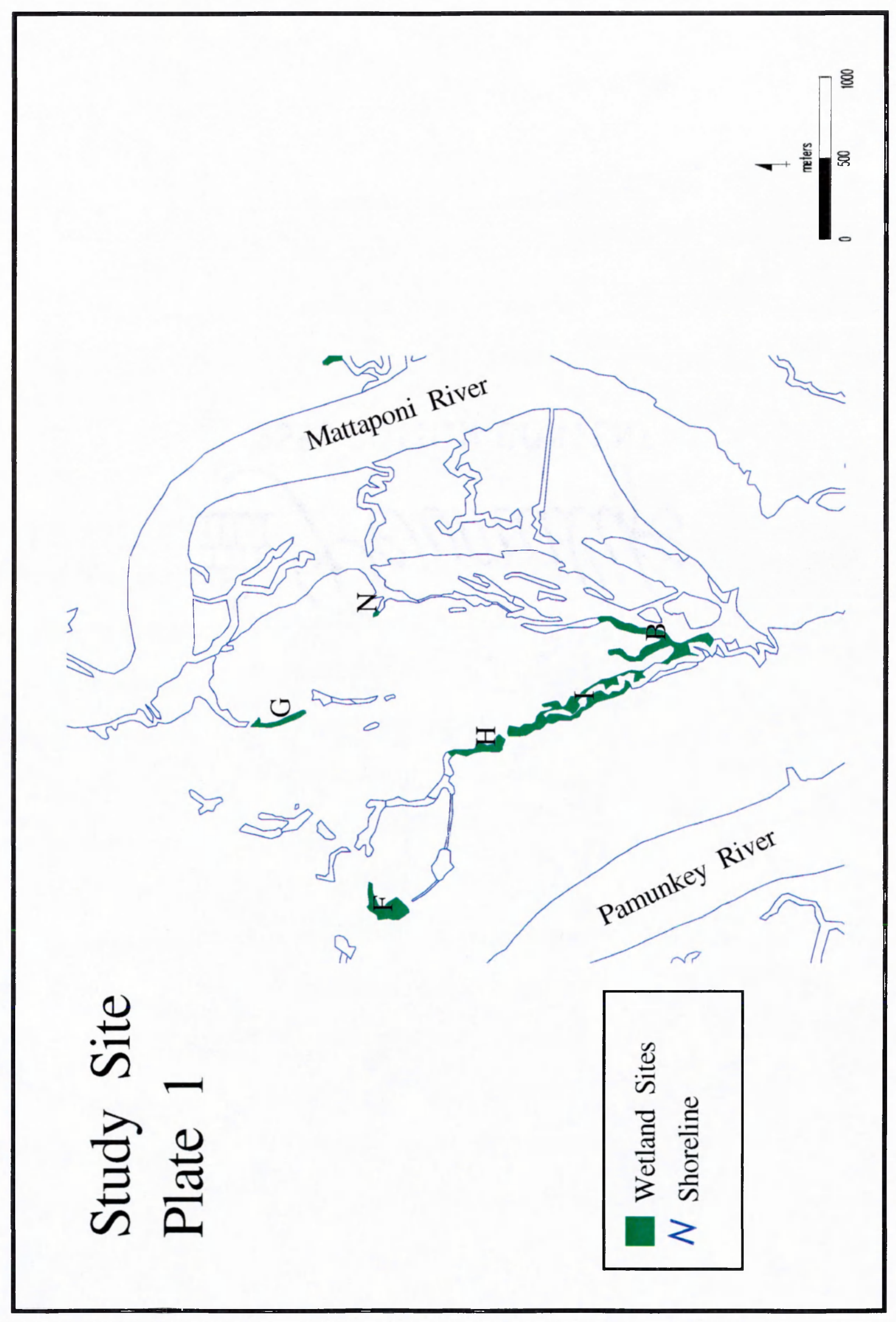




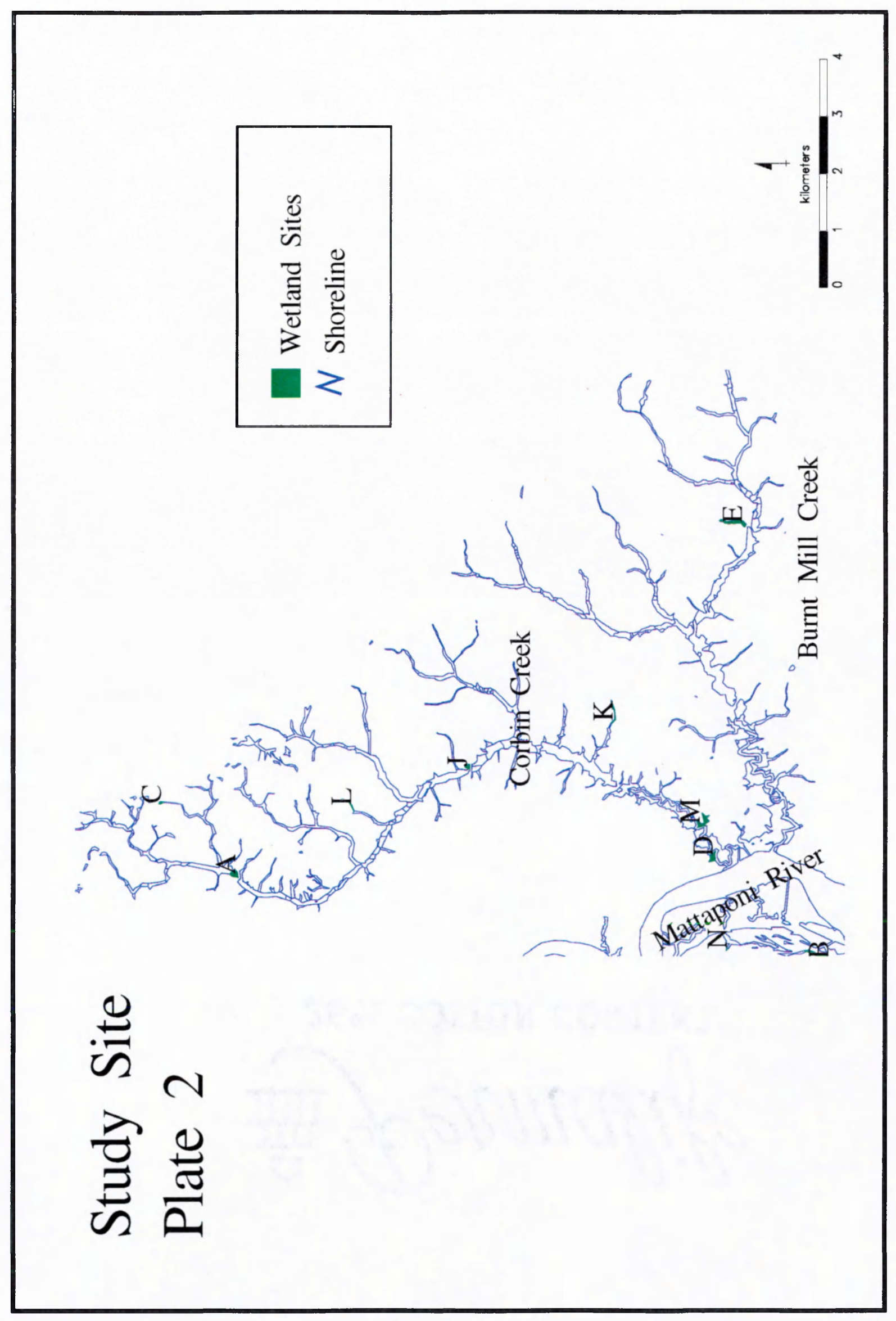


Figure 2. Land use distribution in the watersheds of interest. Land use data are taken from the 1989 NOAA Coastwatch satellite imagery. 


\section{Land Use of the Study Area}

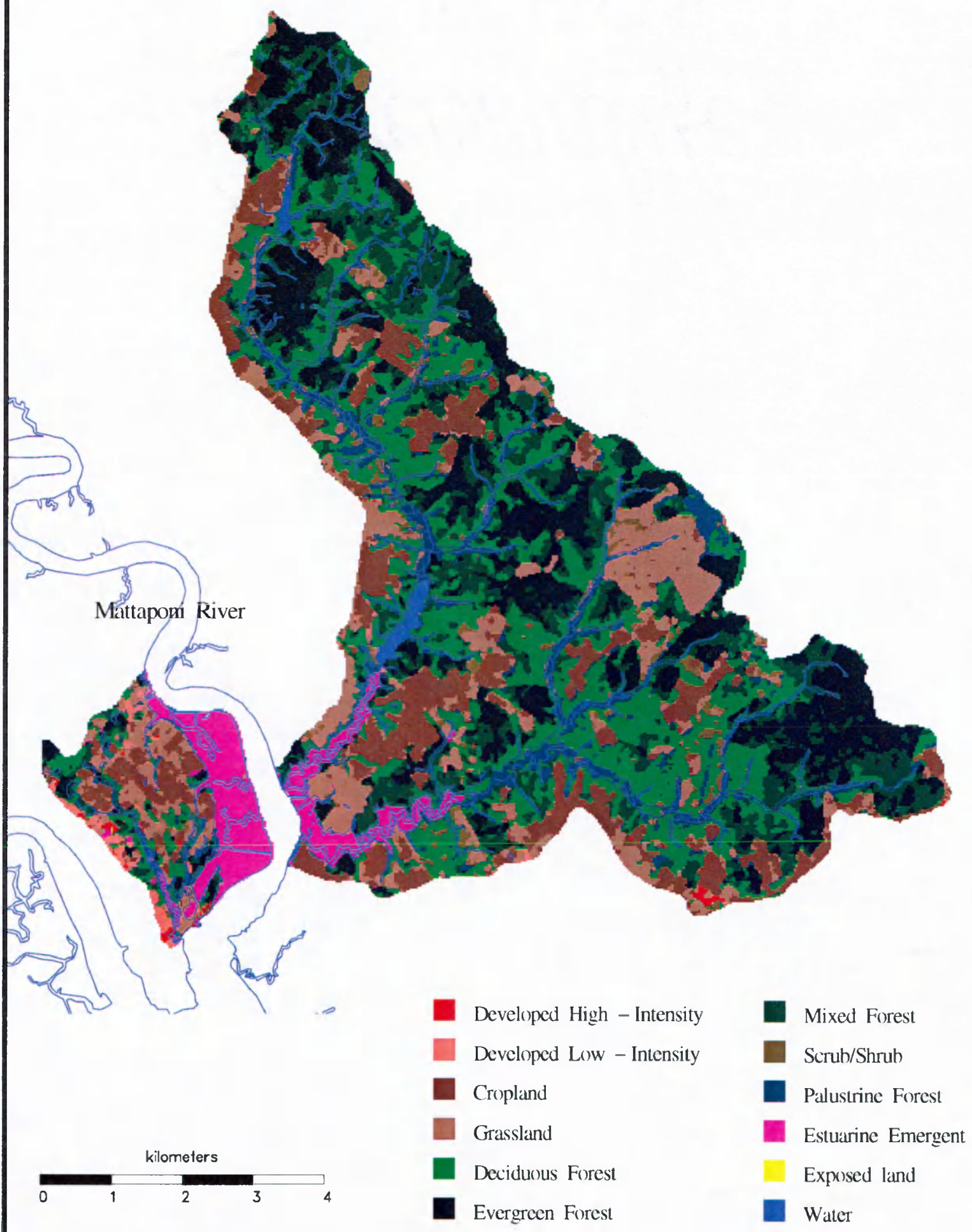




\subsection{Total Phosphorus Retention and Accumulation in Coastal Virginia Wetlands}

\subsection{INTRODUCTION}

Since the 1970's when water quality became a national priority with amendments to the Water Pollution Control Act, water quality issues have received a great deal of attention. Considerable research has focussed on understanding wetland roles in retaining nutrients and pollutants. In fact, the ability of wetlands to act as sinks for certain chemicals, especially sediments and nutrients has been one of the main motivating factors for wetland protection (Heliotis et al. 1983). The wetlands surrounding the Chesapeake Bay have been studied extensively as their role in water quality maintenance may have large economic as well as environmental importance.

Many studies report high phosphorus removal rates by wetlands. Moreover, results of numerous studies have led to serious consideration of the use of wetlands for the treatment of wastewater (Tilton et al. 1979; Spangler et al. 1977; Hammer 1986). Other work has shown that while wetlands may retain total phosphorus for a few years, they have a limited capacity to continually assimilate the nutrient over the long term (Nichols 1983). Intensive inputs of a pollutant or a combination of numerous pollutants, may result in changes in the wetland system itself, resulting in a decreased capacity to store or use nutrients (Tilton et al. 1979; Spangler et al. 1977). Still other studies report that wetlands only retain phosphorus seasonally. Wetlands act as a sink during the growing season due to plant uptake, and as a source of total phosphorus from decomposition (Whigham et al. 1979; Johnston et al. 1984). This has led some to conclude that no net accumulation of total phosphorus in sediments occurs (Simpson et al. 1983). Analysis of historic 
sediments through a combination of sediment dating techniques and sediment nutrient analysis provide another view of wetland-phosphorus interactions; over the long term, it appears that most wetlands do retain some phosphorus. (Table 1) (Yarbro 1983;

Richardson et al. 1986; Peterjohn et al. 1984).

While a consensus exists that wetlands play an important role in water quality, there is no agreement on the actual ability or effectiveness of wetlands in removing phosphorus from the natural landscape. Moreover, there remains much debate surrounding the variability in phosphorus removal by different wetlands. This study was designed to characterize and compare sediment accumulation and total phosphorus retention rates on a 30 year time scale, by analyzing total phosphorus concentrations and grain size distributions in ${ }^{137} \mathrm{Cs}$ dated sediment cores. The hypothesis was that oligohaline wetlands located in the coastal plain of Virginia retain total phosphorus over the long term but at highly variable rates which are influenced by soil characteristics and wetland type.

\subsection{METHODS}

\subsubsection{Wetlands}

National Wetland Inventory maps (1989) were used to identify the wetlands according to the Cowardin classification (1979) method. Two types of wetlands dominate the study area; estuarine emergent and palustrine forested. The estuarine emergent marshes are located mostly in West Point and along the Mattaponi River at the bottom of the watersheds. The palustrine forested wetlands occupy primarily the upper two thirds of Corbin Creek Pond and Burnt Mill Creek watersheds. The remaining wetlands consist of palustrine emergent and palustrine scrub shrub. Two of the samples came from 


\section{TABLE 1}

Summary of literature values of measured wetland total phosphorus retention rates by wetland type. Type is defined by the hydrology and/or dominant vegetation, depending on the information available.

\begin{tabular}{lll}
\hline TYPE & RATE $\left(\mathrm{g} / \mathrm{m}^{2} / \mathrm{yr}\right)$ & \multicolumn{1}{c}{ SOURCE } \\
\hline \hline $\begin{array}{l}\text { alluvial } \\
\text { palustrine } \\
\text { forested }\end{array}$ & $1.9-3.6$ & Mitsch et al. 1979 \\
swamp & $0.17-0.3$ & Peterjohn et al. 1984 \\
freshwater & $0.23-0.24$ & Yarbro 1983 \\
freshwater & $0.005-0.24$ & Richardson 1985 \\
forested & $0.1-0.2$ & Nichols 1983 \\
fen & 9.0 & Likens et al. 1977 \\
\hline
\end{tabular}


impounded wetlands which means that they were hydrologically modified by a barrier, such as a dam or road. United States Geographic Service topographic maps (1986) were used to identify stream order (Strahler 1960) of the study wetlands. Stream order is used as an indicator of the wetland's location within the watershed, based on river flow.

\subsubsection{Field Work}

Sediment cores were collected in the fall of 1993 from each of the 14 wetlands chosen for sampling (Figure 1). All cores were taken within 1 meter of a streambank in an undisturbed section of the wetland. This location was chosen as it was possible to take cores from hydrologically similiar locations from all wetland sites. Two cores were collected from each site using a $50 \mathrm{~cm}$ long PVC tube; one with a diameter of $10 \mathrm{~cm}$, and, the second with a diameter of $5 \mathrm{~cm}$. Cores were stored in an upright position and returned to the lab for analysis.

\subsubsection{Sediment Analysis}

The $10 \mathrm{~cm}$ diameter cores were used for the ${ }^{137} \mathrm{Cs}$ dating. This enabled the calculation of a 30 year sediment accumulation average. The larger diameter PVC was used in order to reduce the effects of compaction. Cores were corrected for compaction assuming uniform compaction of the core prior to slicing into $2 \mathrm{~cm}$ intervals. Core slice wet weights were recorded. Sediments were dried at $105^{\circ} \mathrm{C}$ for 24 hours, ground and dry weights were recorded. Bulk densities were calculated based on the dry weight and the

volume of a two centimeter slice (Allen et al. 1974). ${ }^{137}$ Cs activity was measured using an ORTEC multichannel analyzer. Subsamples were counted for 10 hours and net counts were calculated. Background activity was subtracted from the sample net counts, and 
resultant values were expressed as counts per minute (cpm). The layer of maximum activity (1963) was determined by plotting cesium versus depth. The depth of sediment above this layer was then divided by the number of years elapsed since 1963 (30 years in this case) to determine an average sediment accumulation rate.

The $5 \mathrm{~cm}$ diameter cores were used for the total phosphorus analysis as well as the sediment grain size analysis. The cores were immediately placed in a freezer upon returning from the field. Upon freezing, cores were sliced into three cm intervals, accounting for compaction along the way and assuming uniform compaction.

The analysis used for total phosphorus involved acid extraction techniques (Aspila et al. 1976). Total phosphorus for each sample was calculated in milligrams of phosphorus per gram of sediment. Total phosphorus concentrations were plotted with depth for each site and visually inspected for outliers and patterns with depth.

Two performance indicators pertaining to the role of wetlands in phosphorus retention were calculated using the total phosphorus concentrations, sediment accumulation rates and bulk densities. The first indicator, burial, is equal to the absolute total phosphorus retention of the wetland system in mass per unit area over time (Eq.1). It is a measure of the mean total phosphorus found below the biologically active zone in the collected cores.

$$
\text { BURIAL }=S_{A}\left\{\left(\sum_{i=j}^{z} T_{i} p_{i}\right) / n\right\} C ;
$$

where:

$$
\begin{aligned}
\text { BURIAL } & =\mathrm{g} \text { TP } / \mathrm{cm}^{2} / \mathrm{yr} \\
\mathrm{i} & =\text { sample; } \\
\mathrm{j} & =\text { sample at the biologically active zone; } \\
\mathrm{z} & =\text { sample at bottom of core; }
\end{aligned}
$$


$\mathrm{T}=$ total phosphorus concentration in $\mathrm{mg} \mathrm{TP} / \mathrm{g}$ sediment;

$\mathrm{p}=$ density in grams sediment/cubic centimeter,

$\mathrm{n}=$ number of samples from $\mathrm{j}$ to $\mathrm{z}$;

$\mathrm{S}_{\mathrm{A}}=$ sediment accumulation rate in $\mathrm{cm} / \mathrm{yr}$.

$C=$ conversion factor $\left[(\mathrm{g} / 1000 \mathrm{mg})\left(10000 \mathrm{~cm}^{2} / \mathrm{m}^{2}\right)\right]=10$

The second indicator, loss, is the change in total phosphorus concentrations over time (Eq.2). It is a measure of the amount of total phosphorus lost from the wetland system between the time of initial deposition and long term retention below the biologically active zone.

$$
\text { LOSS }=\left[\left\{\left(T_{\mathrm{a}} \mathrm{p}_{\mathrm{a}}\right)-\left(\mathrm{T}_{\mathrm{j}} \mathrm{p}_{\mathrm{j}}\right)\right\} \mathrm{D}_{\mathrm{j}}\right] /\left(\mathrm{D}_{\mathrm{j}} / \mathrm{S}_{\mathrm{A}}\right) \mathrm{C}
$$

where:

$$
\begin{aligned}
\text { LOSS } & =\mathrm{mg} \mathrm{TP} / \mathrm{cm}^{2} / \mathrm{yr} \\
\mathrm{T} & =\text { total phosphorus concentration in } \mathrm{mg} \mathrm{TP} / \mathrm{g} \text { sediment; } \\
\mathrm{p} & =\text { density }(\mathrm{g} \text { sediment per cubic centimeter }) ; \\
\mathrm{a} & =\text { sample at depth of initial deposition }(\mathrm{top}) ; \\
\mathrm{j} & =\text { sample at depth of biologically active zone; } \\
\mathrm{D} & =\text { depth of sample; } \\
\mathrm{S}_{\mathrm{A}} & =\text { sediment accumulation rate in } \mathrm{cm} / \mathrm{yr} . \\
\mathrm{C} & =\text { conversion factor }\left[(\mathrm{g} / 1000 \mathrm{mg})\left(10000 \mathrm{~cm}^{2} / \mathrm{m}^{2}\right)\right]=10
\end{aligned}
$$

Grain size fractions were measured using wet sieving and pipetting methods as outlined in Folk (1980). Percentages of silt, clay, sand and gravel were determined for each subsample.

\subsubsection{Statistical Analysis}

The Pearson correlation coefficient was used to explore relationships of silt, clay, depth and total phosphorus. A linear regression in SAS (1985), was used to test for a linear relationship between silt and clay percentages and total phosphorus concentrations.

\subsection{RESULTS AND DISCUSSION}

The ${ }^{137} \mathrm{Cs}$ analysis resulted in four interpretable profiles, showing clear peaks which 
were interpreted as the 1963 peak from atmospheric fall out (Figure 3). Sediment accumulation rates calculated from these profiles were $3.0,3.7,4.3$ and $5.6 \mathrm{~mm} / \mathrm{yr}$. Based on a survey of literature for similiar wetlands (Table 2), these values fall well within the documented range of 2.0-8.1 mm/yr for freshwater wetlands (Stevenson et al. 1986, Khan et al. 1994).

Total phosphorus retention rates ranged from 0.05 to $0.72 \mathrm{~g} \mathrm{TP} / \mathrm{m}^{2} / \mathrm{yr}$ using the low sediment accumulation rate of $3.0 \mathrm{~mm} / \mathrm{yr}$, and from 0.09 to $1.30 \mathrm{~g} \mathrm{TP} / \mathrm{m}^{2} / \mathrm{yr}$ using a high sediment accumulation rate of $5.6 \mathrm{~mm} / \mathrm{yr}$ (Figure 4). The loss indicator, measuring the change in total phosphorus concentration over time in surficial sediments, ranged from 0.02 to $1.15 \mathrm{~g} \mathrm{TP} / \mathrm{m}^{2} / \mathrm{yr}$ with a sediment accumulation rate of $3.0 \mathrm{~mm} / \mathrm{yr}$, and from 0.04 to $2.15 \mathrm{~g} \mathrm{TP} / \mathrm{m}^{2} / \mathrm{yr}$ using a sediment accumulation rate of $5.6 \mathrm{~mm} / \mathrm{yr}$ (Table 3). The calculated total phosphorus retention is similiar to literature values for freshwater wetlands (see Table 1).

The literature reports total phosphorus retention rates by wetland type. While the sampled wetlands included 10 palustrine, with two being impounded, and four estuarine wetlands, there was no evidence that total phosphorus retention differed between wetland types (Table 4). However, the impounded wetlands have a consistently higher total phosphorus retention rate. The higher retention in the impounded wetlands is not very surprising as there is a physical barrier across the wetlands obstructing the outflow of water. This inhibits output of sediments and nutrients. The remaining palustrine and estuarine wetlands in the study have total phosphorus retention rates that vary by as much as three orders of magnitude. 
Figure 3. $\quad{ }^{137} \mathrm{Cs}$ profiles with depth for the four successful sites. Sites are D, F, I and $\mathrm{J}$ which are located on Figure $1 .{ }^{137} \mathrm{Cs}$ is in counts per minute. Count peaks are interpreted as the 1963 maximum in atmospheric fallout form bomb testing. 
[137Cs] (cpm)
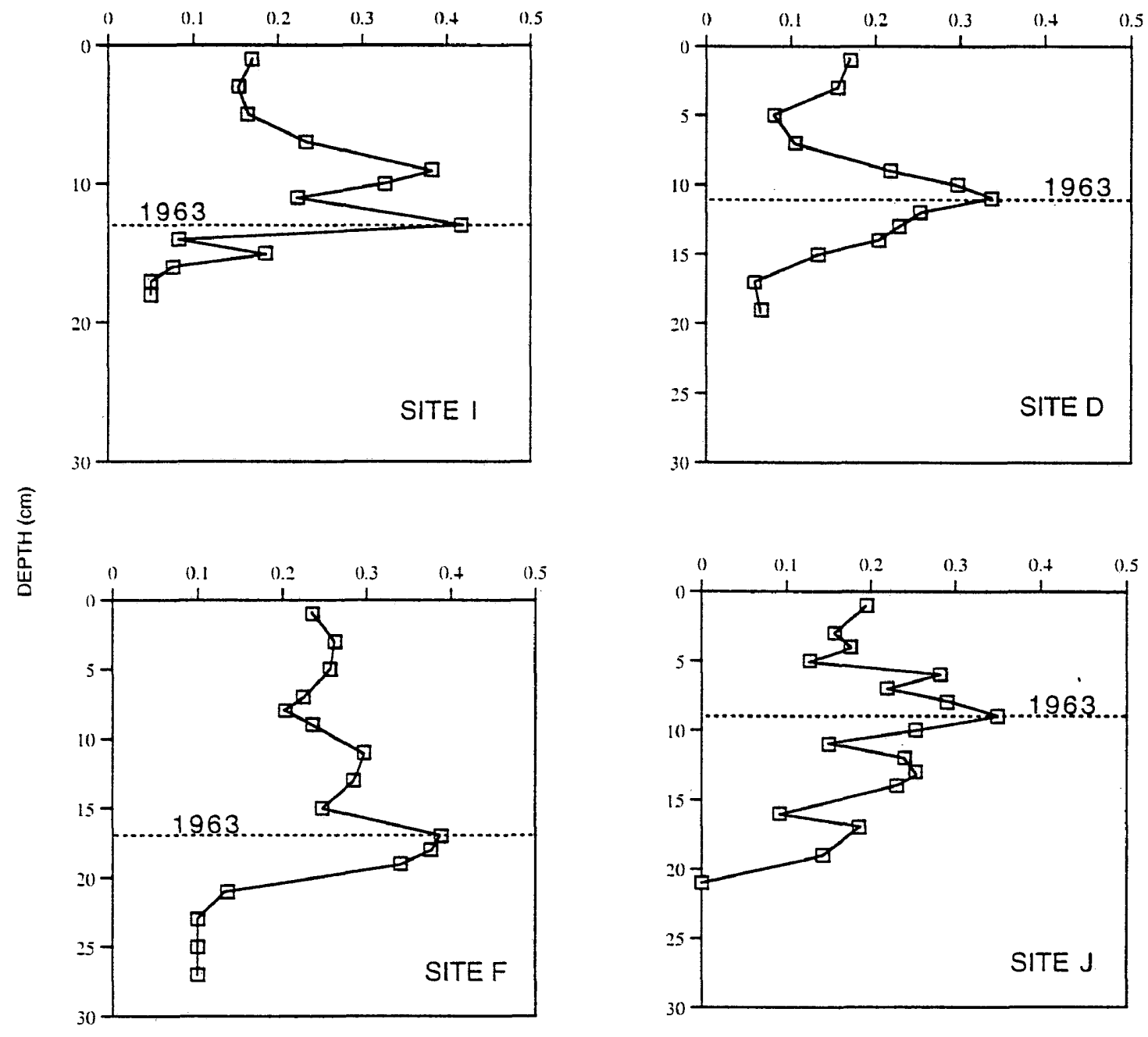


\section{TABLE 2}

Summary of literature values of measured wetland sediment accumulation rates along the east coast of the U.S. by state and by wetland type. Wetland type is defined by the hydrology and/or dominant species of the sampled wetland, depending on the information available.

\begin{tabular}{llll}
\hline LOCATION & TYPE & $\begin{array}{c}\text { ACCUMULATION } \\
(\mathrm{mm} / \mathrm{yr})\end{array}$ & SOURCE \\
\hline Maine & tidal & $0-13$ & Wood et al. 1989 \\
Virginia & tidal saltmarsh & 6.8 & Wilcox 1989 \\
Virginia & fringe & $1-2.2$ & Oertel et al. 1989 \\
Florida & peatlands & $1.6-4.0$ & Craft et al. 1993 \\
New York & tidal & $2.5-6.3$ & Hatton et al. 1983 \\
Delaware & tidal & $5.0-6.3$ & Hatton et al. 1983 \\
Connecticut & tidal & $8-10$ & Hatton et al. 1983 \\
Maryland & $\begin{array}{l}\text { freshwater tidal } \\
\text { - highmarsh }\end{array}$ & $5.2^{*}$ & Khan et al. 1994 \\
& - lowmarsh & $5.8^{*}$ & \\
\hline
\end{tabular}

* average of rates found from 1964 to present 


\section{TABLE 3}

Wetland burial and loss, calculated from equations one and two. Site refers to the areas A-N, located on Figure 1. TP Burial, calculated using equation 1 is the total phosphorus retention. Loss, calculated using equation 2 , is the change in total phosphorus concentration over time in the surficial sediments.

\begin{tabular}{lllll}
\hline SITE & $\begin{array}{l}\text { TP Burial } \\
\left(\mathrm{g} / \mathrm{m}^{2} / \mathrm{yr}\right)\end{array}$ & \multicolumn{2}{c}{$\begin{array}{l}\text { Loss } \\
\left(\mathrm{g} / \mathrm{m}^{2} / \mathrm{yr}\right)\end{array}$} \\
\hline \hline & low & high & low & high \\
\hline A & 0.30 & 0.54 & & \\
B & 0.72 & 1.30 & 0.14 & 0.26 \\
C & 0.13 & 0.23 & 0.45 & 0.84 \\
D & 0.11 & 0.20 & 0.13 & 0.24 \\
E & 0.26 & 0.47 & 0.03 & 0.06 \\
F & 0.11 & 0.20 & 0.13 & 0.24 \\
G & 0.06 & 0.11 & 0.05 & 0.09 \\
H & 0.34 & 0.61 & 0.67 & 1.25 \\
I & 0.11 & 0.20 & 1.15 & 2.15 \\
J & 0.39 & 0.70 & 0.04 & 0.07 \\
K & 0.07 & 0.13 & 0.02 & 0.04 \\
L & 0.08 & 0.14 & 0.04 & 0.07 \\
M & 0.11 & 0.20 & 0.16 & 0.30 \\
N & 0.05 & 0.09 & 0.05 & 0.09 \\
& & & 0.15 & 0.28 \\
\hline
\end{tabular}




\section{TABLE 4}

Wetland burial and loss indicators, summarized by wetland type. Wetland type is defined by Cowardin (1979); $\mathrm{PF}=$ palustrine forested; $\mathrm{EE}=$ estuarine emergent; $\mathrm{PH}=$ palustrine dammed; PSS = palustrine scrub shrub; $P E=$ palustrine emergent. Site refers to areas A$\mathrm{N}$, located on Figure 1. TP burial is the calculated amount of total phosphorus retention. Loss is the change in total phosphorus concentration over time occurring in the surficial sediments. The low $(\mathrm{L})$ and high $(\mathrm{H})$ values represent the range of burial and loss values calculated using sediment accumulation values of $3.0 \mathrm{~mm} / \mathrm{yr}$ and $5.6 \mathrm{~mm} / \mathrm{yr}$.

\begin{tabular}{|c|c|c|c|c|c|c|c|}
\hline Type & Site & $\begin{array}{l}\text { TP F } \\
(\mathrm{g} / \mathrm{m}\end{array}$ & $\begin{array}{l}\text { urial } \\
\text { (yr) }\end{array}$ & $\begin{array}{r}\operatorname{Los} \\
\left(\mathrm{g} / \mathrm{m}^{2}\right. \\
\end{array}$ & s & $\begin{array}{l}\text { Mean } \\
\text { Buria }\end{array}$ & \\
\hline & & low & high & low & high & low & high \\
\hline PF & A & 0.30 & 0.54 & 0.14 & 0.26 & 0.15 & 0.27 \\
\hline & C & 0.13 & 0.23 & 0.13 & 0.24 & & \\
\hline & F & 0.11 & 0.20 & 0.05 & 0.09 & & \\
\hline & $\mathbf{K}$ & 0.07 & 0.13 & 0.04 & 0.07 & & \\
\hline $\mathrm{EE}$ & B & 0.72 & 1.30 & 0.45 & 0.84 & 0.26 & 0.47 \\
\hline & D & 0.11 & 0.20 & 0.03 & 0.06 & & \\
\hline & I & 0.11 & 0.20 & 0.04 & 0.07 & & \\
\hline & $\mathbf{M}$ & 0.11 & 0.20 & 0.05 & 0.09 & & \\
\hline PH & $E$ & 0.26 & 0.47 & 0.13 & 0.24 & 0.33 & 0.59 \\
\hline & $\mathbf{J}$ & 0.39 & 0.70 & 0.02 & 0.04 & & \\
\hline PSS & G & 0.06 & 0.11 & 0.67 & 1.25 & 0.06 & 0.11 \\
\hline & L & 0.08 & 0.14 & 0.16 & 0.30 & & \\
\hline & $\mathrm{N}$ & 0.05 & 0.09 & 0.15 & 0.28 & & \\
\hline $\mathrm{PE}$ & $\mathrm{H}$ & 0.34 & 0.61 & 1.15 & 2.15 & 0.34 & 0.61 \\
\hline
\end{tabular}


Some of the difference in total phosphorus retention between the literature values and the range of results found here may be attributed to different methods used to calculate phosphorus retention. Numerous studies of phosphorus retention calculated rates based on short cores $(10 \mathrm{~cm})$; while other studies failed to provide an explicit definition of phosphorus burial preventing clear interpretation of their findings. Total phosphorus retention calculated here are long term averages (30+ years), from 30 centimeter plus long cores, and did not include the top section of the core. This was justified by the fact that the average for the top section of many of the phosphorus profiles was noticeably higher and more variable than the lower section where total phosphorus concentrations were more uniform (Figure 3). Plant uptake and phosphorus additions from plant decomposition may increase the variability and amount of total phosphorus found in surficial sediments. Thus, surficial total phosphorus concentrations are more indicative of short term storage influenced by plant uptake, decomposition and microbial activities (Walbridge 1991).

The data do suggest that total phosphorus retention may vary by location, as defined by stream order (Table 5). The sampled wetlands were located on first, second and third order streams. Lower total phosphorus retention was found in the wetlands located on first order streams while the higher total phosphorus retention was found in wetlands located on the third order streams. Stream order and total phosphorus retention were significantly correlated, using the Pearson correlation $(\mathrm{r}=0.68, \mathrm{p}<0.005, \mathrm{~N}=14)$. Generally, wetlands located on first order streams are located near the headwaters of the watershed, offering less opportunity for phosphorus to be accumulated in surface water 
Figure 4. Total phosphorus concentration profiles with depth for each sample. Total phosphorus concentrations are in milligrams of total phosphorus per gram of sediment. Site refers to areas A -N, located on Figure 1. Subsamples were taken every three centimeters in depth. 

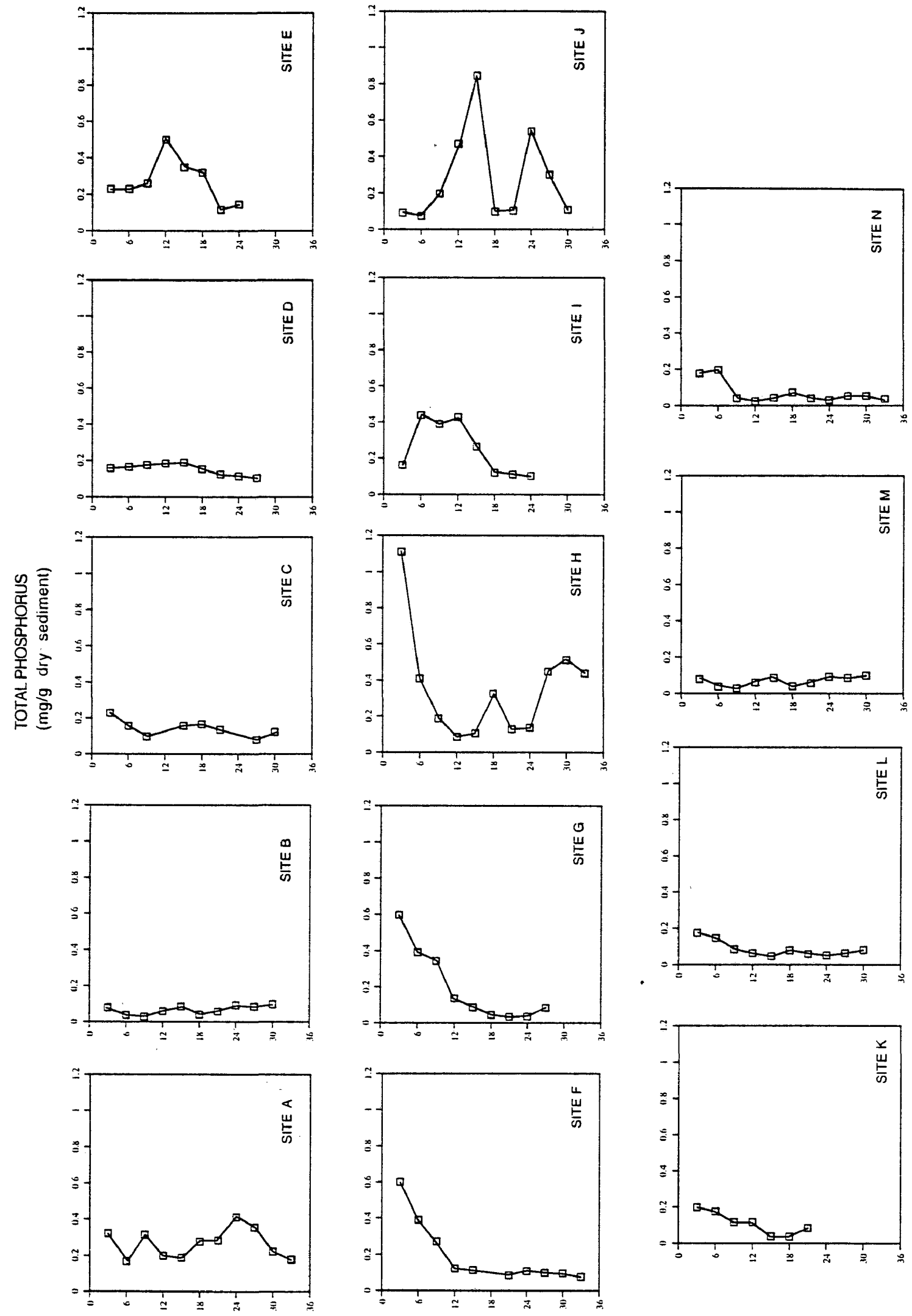

(யง) $H \perp d \exists O$ 


\section{TABLE 5}

Wetland burial and loss indicators, summarized by stream order location (Strahler, 1960). Site refers to areas A-N, located on Figure 1. TP burial is the calculated total phosphorus retention. Loss is the change in total phosphorus concentration over time occurring in the surficial sediments. The low $(\mathrm{L})$ and high $(\mathrm{H})$ values represent the range of burial and loss values calculated using sediment accumulation values of $3.0 \mathrm{~mm} / \mathrm{yr}$ and $5.6 \mathrm{~mm} / \mathrm{yr}$.

\begin{tabular}{|c|c|c|c|c|c|c|c|}
\hline \multirow[t]{2}{*}{$\begin{array}{l}\text { Stream } \\
\text { order }\end{array}$} & \multirow[t]{2}{*}{ Site } & \multicolumn{2}{|c|}{$\begin{array}{l}\text { TP Burial } \\
\left(\mathrm{g} / \mathrm{m}^{2} / \mathrm{yr}\right)\end{array}$} & \multicolumn{2}{|c|}{$\begin{array}{c}\text { Loss } \\
\left(\mathrm{g} / \mathrm{m}^{2} / \mathrm{yr}\right)\end{array}$} & \multicolumn{2}{|c|}{$\begin{array}{l}\text { Mean } \\
\text { Burial }\end{array}$} \\
\hline & & low & high & low & high & low & high \\
\hline \multirow[t]{7}{*}{1} & C & 0.13 & 0.23 & 0.13 & 0.24 & 0.09 & 0.16 \\
\hline & $\mathrm{F}$ & 0.11 & 0.20 & 0.05 & 0.09 & & \\
\hline & $\mathrm{G}$ & 0.06 & 0.11 & 0.67 & 1.25 & & \\
\hline & $\mathrm{K}$ & 0.07 & 0.13 & 0.04 & 0.07 & & \\
\hline & $\mathrm{L}$ & 0.08 & 0.14 & 0.16 & 0.30 & & \\
\hline & $\mathbf{M}$ & 0.11 & 0.20 & 0.05 & 0.09 & & \\
\hline & $\mathrm{N}$ & 0.05 & 0.09 & 0.15 & 0.28 & & \\
\hline \multirow[t]{3}{*}{2} & A & 0.30 & 0.54 & 0.14 & 0.26 & 0.25 & 0.45 \\
\hline & $\mathrm{H}$ & 0.34 & 0.61 & 1.15 & 2.15 & & \\
\hline & I & 0.11 & 0.20 & 0.04 & 0.07 & & \\
\hline \multirow[t]{4}{*}{3} & B & 0.72 & 1.30 & 0.45 & 0.84 & 0.37 & 0.67 \\
\hline & D & 0.11 & 0.20 & 0.03 & 0.06 & & \\
\hline & $\mathrm{E}$ & 0.26 & 0.47 & 0.13 & 0.24 & & \\
\hline & $\mathrm{J}$ & 0.39 & 0.70 & 0.02 & 0.04 & & \\
\hline
\end{tabular}


flow. The reduced opportunity of the wetlands to retain phosphorus may explain some of the variation in the total phosphorus retention.

The grain size analysis showed the wetlands sampled to be predominantly sandy environments in all but three of the sites (Table 6). The Pearson correlation coefficient for silt, clay and depth showed that only clay was significantly correlated with total phosphorus $(r=0.58, p<0.001, N=120)$ and depth. Regression of the clay against total phosphorus was significant $(\mathrm{p}=0.005, \mathrm{~N}=120)$. However, it was weak as a predictive measure $\left(r^{2}=0.5\right)$, again indicating that other factors are important in explaining the variation of total phosphorus in the sediment.

Generally, it is believed that the sorption of phosphorus onto clay particles is particularly important as a large portion of phosphorus input is through sedimentation processes (Mitsch et al. 1993). However, phosphorus concentrations are also strongly tied to the amount of aluminum or iron ions present in the substrate (Mitsch et al. 1993). Phosphorus removal in wetlands occurs through the adsorption of phosphorus not only to clay particles, but also to organic peat, ferric and aluminum hydroxides and oxides (Reed et al. 1989).

\subsection{CONCLUSIONS}

The wetlands studied accumulated sediment $(3.0-5.6 \mathrm{~mm} / \mathrm{yr})$ and retained total phosphorus over a 30 year time frame. These sediment accumulation rates are within the range of values in other parts of the country (Stevenson et al. 1986; Khan et al. 1994;

Nixon 1980). Total phosphorus retention ranged from 0.05 to $0.72 \mathrm{~g} \mathrm{TP} / \mathrm{m}^{2} / \mathrm{yr}$ assuming the lowest sediment accumulation rate of $3.0 \mathrm{~mm} / \mathrm{yr}$ and from 0.09 to $1.30 \mathrm{~g} \mathrm{TP} / \mathrm{m}^{2} / \mathrm{yr}$ 


\section{TABLE 6}

Average sediment grain size and bulk density of each site. Site refers to areas A-N located on Figure 1.

\begin{tabular}{|c|c|c|c|c|c|}
\hline SITE & GRAVEL (\%) & SAND $(\%)$ & $\operatorname{SILT}(\%)$ & CLAY $(\%)$ & $\begin{array}{c}\text { BULK } \\
\text { DENSITY }\left(\mathrm{g} / \mathrm{cm}^{3}\right) \\
\end{array}$ \\
\hline $\mathbf{A}$ & 0.1 & 92.3 & 3.5 & 4.1 & 0.39 \\
\hline B & 11.4 & 8.1 & 32.0 & 48.5 & 0.37 \\
\hline $\mathrm{C}$ & 30.3 & 44.3 & 20.2 & 5.2 & 0.33 \\
\hline D & 3.7 & 74.3 & 13.4 & 8.6 & 0.35 \\
\hline $\mathrm{E}$ & 0 & 80.5 & 11.8 & 7.7 & 0.37 \\
\hline $\mathrm{F}$ & 10.3 & 74.1 & 6.9 & 8.7 & 0.19 \\
\hline G & 9.4 & 87.1 & 2.8 & 0.7 & 0.49 \\
\hline $\mathrm{H}$ & 1.1 & 66.5 & 27.5 & 4.9 & 0.38 \\
\hline I & 2.2 & 79.1 & 10.0 & 8.7 & 0.35 \\
\hline $\mathbf{J}$ & 0 & 91.0 & 5.3 & 3.7 & 0.40 \\
\hline $\mathbf{K}$ & 0.4 & 76.6 & 15.1 & 7.9 & 0.34 \\
\hline $\mathrm{L}$ & 0.5 & 76.3 & 15.5 & 7.7 & 0.36 \\
\hline $\mathbf{M}$ & 1.8 & 82.3 & 11.4 & 4.5 & 0.45 \\
\hline $\mathrm{N}$ & 2.2 & 92.5 & 4.5 & 0.8 & 0.31 \\
\hline
\end{tabular}


assuming the highest sediment accumulation rate of $5.6 \mathrm{~mm} / \mathrm{yr}$. Total phosphorus retention was within the range of values found for both freshwater and palustrine forested wetlands (Nichols 1983; Richardson 1985; Peterjohn et al. 1984). Clay was found to be significantly correlated with total phosphorus concentration, although relatively weak as a predictive measure. Total phosphorus concentrations may be highly correlated with organic peat, ferric and aluminum hydroxides and oxides (Reed et al. 1989).

Results of this study demonstrated that total phosphorus retention can not be predicted by wetland type. Only impounded wetlands were found to retain higher than average total phosphorus concentrations. This is most likely a result of the greater water retention times.

Total phosphorus retention was found to be highly correlated with wetland location, as defined by stream order. This indicates that wetland management needs to incorporate some analysis and understanding of the effects of surrounding land use and wetland position within a watershed on wetland functioning.

The two above findings concerning total phosphorus retention have important wetland management implications; mitigation and creation of wetlands based simply on wetlands type may not provide a good estimate of the functional losses that may be occurring. Understanding the effect of wetland location on its functioning is crucial for proper decision making regarding wetland mitigation and creation efforts. 


\subsection{Watershed analysis of wetland total phosphorus retention using Geographic}

\section{Information Systems.}

\subsection{INTRODUCTION}

The ability of wetlands to retain nutrients and pollutants may be influenced by sediment characteristics (Richardson 1985), hydrology (Walker 1987) and surface water run-off (Sonzogni et al. 1980, Grobler et al. 1985). While numerous studies have focussed on wetland sediments, chemistry and hydrology, research related to wetland phosphorus retention as a function of landscape position and the influence of upland land use has been limited. Upland land uses are known to release different surface run-off loads of nutrients and pollutants which may affect the potential for wetland retention (Mitsch et al. 1993; Craft et al. 1993). Evaluation of the actual water quality role of

. wetlands in a watershed therefore, not only requires information about wetland sediment and hydrology characteristics, but also knowledge of upland land use and wetland position within the watershed. Wetland water quality functions in the Chesapeake Bay watershed are of particular importance as the water quality of the Chesapeake Bay has economic as well as ecological consequences for the region.

Recent examples of landscape approaches to wetland nutrient functions include Craft and Richardson (1993), Peterjohn and Correll (1984) and Detenbeck et al. (1993). Craft and Richardson (1993) found that soil phosphorus concentrations were two to three times higher in peatlands receiving enriched agricultural runoff, as compared to peatlands receiving unenriched runoff. Peterjohn and Correll (1984), studied the effects of landscape pattern on the distribution of nutrients, and found that the extent and location of 
riparian forests within a watershed could have a major influence on the nutrient dynamics of the landscape. They also concluded that surface water flow was the dominant pathway for phosphorus input to wetlands. Numerous researchers have shown that run-off loadings can be adequately predicted based on the dominant land use present in wetlands (Rast et al. 1983; Beulac et al. 1982). Table 7 summarizes some literature values for total phosphorus run-off loads. Detenbeck et al. (1993), found that both the extent and the position of wetlands in a watershed must be considered when determining the effects of wetlands on lake water quality. They suggested that for non point source loadings, created wetlands could be sited strategically in the lower regions of a watershed in order to protect water quality.

The primary objective of this study was to determine watershed phosphorus throughput in oligohaline coastal wetlands and to relate these amounts to watershed structure (such as land use areas). As well, Geographic Information Systems (GIS) and land use simulations were employed to explore the effect of watershed structure on phosphorus throughput.

\subsection{METHODS}

\subsubsection{Watershed Characterization}

Data used in this study were collected from three sources. National Wetland Inventory (NWI) (USGS, 1989) maps were used to document the location, extent and type of all wetlands in the study area. Wetlands classification used for NWI maps is based on the method of Cowardin et al.(1979).

U.S.G.S topographic maps (1986) were used to define drainage patterns and to 


\section{TABLE 7}

Summary of annual non point loading factors for total phosphorus. Based on average predicted loadings by land use categories provided by a literature survey of calculated values. High and low values were used for run-off load analysis.

\begin{tabular}{lll}
\hline Land Use & $\begin{array}{c}\text { Total Phosphorus } \\
(\mathrm{kg} / \mathrm{ha} / \mathrm{yr})\end{array}$ & Source \\
\hline Residential & 1.6 & Marsalek 1978 \\
& $1.0-2.5$ & EPA 1983 \\
& 1.8 & Wanielista 1978 \\
& 1.5 & Anderson et al. 1981 \\
& 1.2 & Whipple 1978 \\
Commercial & 3.4 & Marsalek 1978 \\
& 1.5 & Bannerman et al. 1978 \\
& 2.2 & EPA 1983 \\
& 2.7 & Wanielista 1978 \\
& & \\
Pasture & 0.5 & Wanielista 1978 \\
& 0.7 & Beulac et al. 1982 \\
& $0.3-0.6$ & Mackiernan 1985 \\
& & \\
Agriculture & 2.2 & Beulac et al. 1982 \\
& 1.1 & Wanielista 1978 \\
& 1.7 & Mackiernan 1985 \\
& 2.9 & Loehr 1974 \\
& & \\
Forest & 0.10 & Wanielista 1978 \\
& 0.25 & Beulac et al. 1982 \\
& $0.06-0.11$ & Mackiernan 1985 \\
& & \\
\hline
\end{tabular}


delineate primary watersheds for each wetland. Primary watersheds are defined as the area from which runoff flows directly into the wetland of interest. Watersheds and wetland boundaries were digitized using ARC/INFO (ESRI, 1992).

The 1989 NOAA Coastwatch data were used to document existing land uses. Fourteen categories of land use are recognized by Coastwatch and are listed on Figure 2. For this study, the land use categories were grouped into six more general categories of ; wetland, pasture, agriculture, forest, residential and commercial development. NWI and Coastwatch differed significantly in identification of wetlands in the study area (Coastwatch indicated only $30 \%$ as many wetlands as NWI). The difference lay primarily in discrimination of palustrine forested wetlands and upland forests. For this study, NWI was assumed to be correct (based on extensive ground truthing in the area), and all land use calculations were based on Coastwatch data outside of NWI delineated wetlands. The land use data were in raster format and were analyzed using ERDAS software (ERDAS Inc. 1994). Watershed and wetland boundary vectors were combined with the land use raster file using the ERDAS Image Interpreter module. This allowed land use area calculations for each primary watershed of interest.

\subsubsection{Watershed Analysis}

Principal component analysis and regression were used to test the hypothesis that a relationship exists between watershed characteristics adjacent to a wetland and the wetland's phosphorus retention/loss function as defined in section 3 . The fourteen wetland sites, shown in Figure 1 were used. Eight variables were used to describe watershed characteristics around each wetland sample. The variables included: 
developed, agriculture, pasture, forest, wetland (area of each major land use); shape (the ratio of a wetland's area to its perimeter); Matt (the distance from a wetland to the Mattaponi River); and shed (ratio of wetland area to its primary watershed area).

Principal component analysis was used to reduce the number of independent variables. Procedure stepwise in SAS (1985) was used to regress the resulting principal components against the two dependent variables of phosphorus burial (retention) and loss rate (see Table 3).

Lastly, using Equations 1 and 4, shown below, indices of wetland "burial" and relative efficiency were calculated. The purpose of this exercise was to estimate and compare the absolute amount of wetland total phosphorus burial to its relative contribution to the watershed.

\subsubsection{Cumulative Watershed Analysis}

GIS and land use simulations were used to explore the effect of watershed structure on phosphorus throughput. The ultimate goal was to see how wetland position and land use patterns within a watershed may affect the cumulative water quality at different locations in the watershed. This analysis was completed by calculating and comparing four indicators (Eq 1-4 below) of wetland contributions to cumulative watershed total phosphorus budgets for Corbin Creek watershed with 1) its current land use patterns and 2) under simulated land use changes.

For practical purposes, Corbin Creek watershed was divided into 13 subwatersheds (zones) as opposed to analyzing each wetland and its watershed separately (Figure 5). These zones provided sufficient detail within the Corbin Creek watershed to 


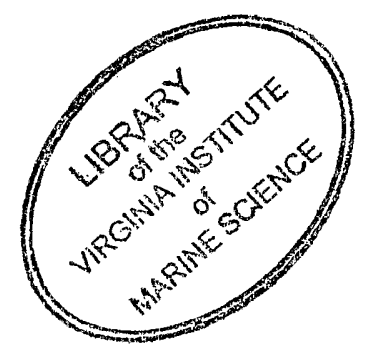

Figure 5. Schematic of the Corbin Creek Pond watershed "zones" used for the cumulative watershed calculations. 


\section{Corbin Creek Watershed}

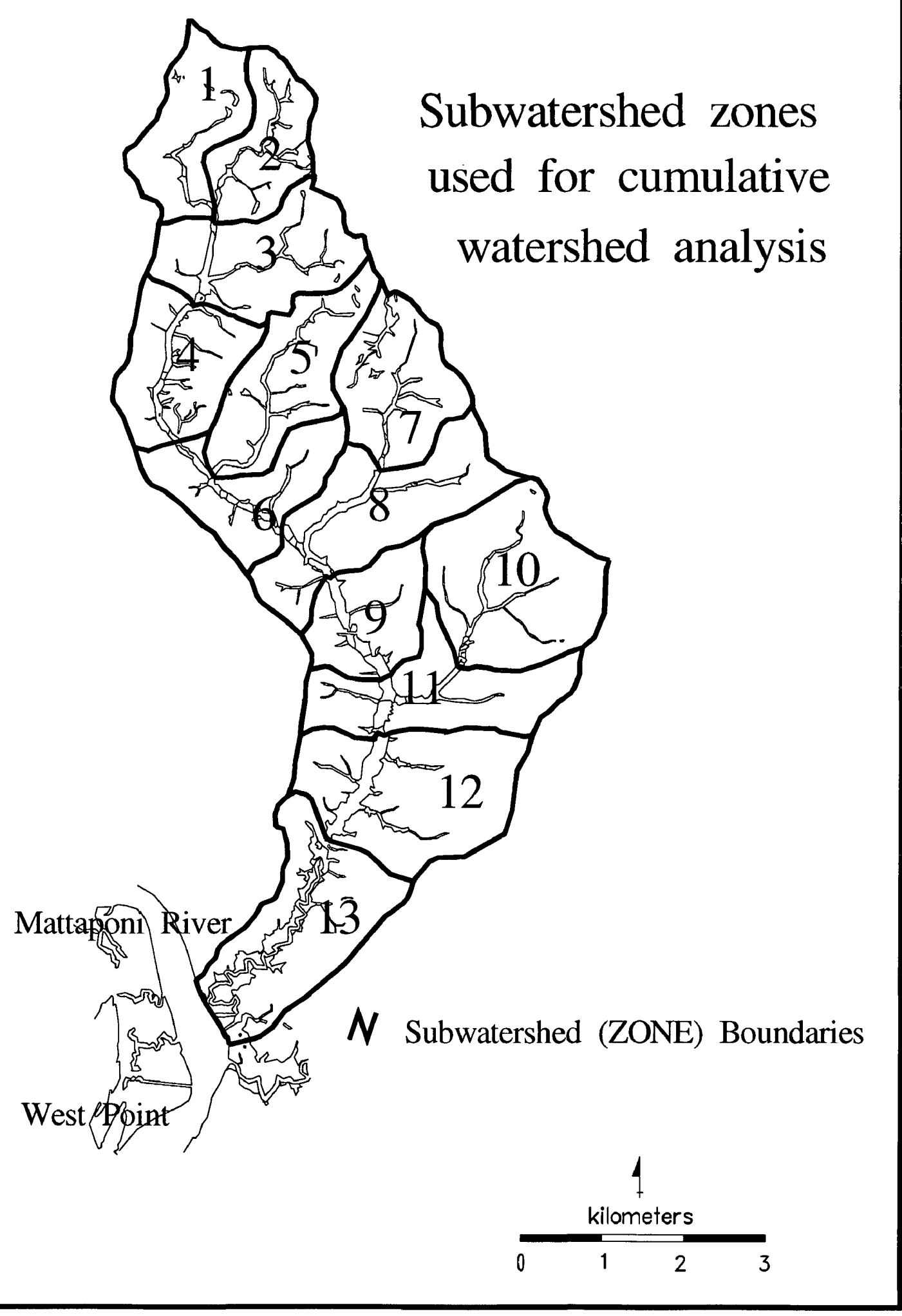


evaluate and compare changes in total phosphorus throughput at different locations in the watershed. Within each zone, all wetland areas were added together and the upland land uses in the zone were treated as one watershed of interest.

Two different land use changes were made; one involved simulating commercial and residential development at the watershed headwaters, and creating wetlands along the Mattaponi River (hereafter referred to as top); the opposite scenario was tested with commercial and residential development along the Mattaponi River, and wetland creation at the watershed headwaters (hereafter referred to as bottom). The proportions of different land uses were made equal for top and bottom development, but distribution varied. In comparison to the current land use, the simulated development for both top and bottom resulted in a $4.6 \%$ increase in high developed land use, $12.4 \%$ increase in low developed land uses, a $13.6 \%$ decrease in forested land use and decreases of $0.6 \%, 1.1 \%$ and $1.5 \%$ in grasslands, croplands and wetland land uses, respectively (Table 8). Top development involved residential and commercial construction of the forested and wetland areas within zones 1 through 4 (Fig.3). In contrast, bottom development involved development of forested areas in zones 10 through 12 and increased wetlands in the top zones.

Indicators of wetland contributions to cumulative watershed total phosphorus budgets were calculated and compared between the different land use simulations as well as for the fourteen wetland samples. Cumulative functioning was assumed to be additive, with the watershed cumulative throughput equal to the throughput of all thirteen zones added together. The following four equations were solved for each of the thirteen zones 


\section{TABLE 8}

Summary of forested (for), developed (dev) and wetland (wet) land use percentages for Corbin Creek Pond with current land use, and the two simulated land use changes; top and bottom development. Changes in the remaining land use categories of grasslands and croplands were less than $1.0 \%$. Zones are defined in Figure 5.

\begin{tabular}{|l|rcc|ccc|ccc|}
\hline & \multicolumn{3}{|c|}{ CURRENT } & \multicolumn{3}{|c|}{ TOP } & \multicolumn{3}{c|}{ BOTTOM } \\
\hline & for & dev & wet & for & dev & wet & for & dev & wet \\
\hline ZONE 1 & 81.7 & 0.2 & 8.5 & 12.0 & 76.0 & 4.3 & 68.0 & 0.2 & 22.2 \\
\hline ZONE 2 & 83.5 & 0 & 16.5 & 4.7 & 91.7 & 3.6 & 83.5 & 0 & 16.5 \\
\hline ZONE 3 & 39.9 & 0 & 17.8 & 0 & 90.6 & 9.4 & 39.9 & 0 & 38.2 \\
\hline ZONE 4 & 86.4 & 0 & 12.3 & 9.6 & 83.8 & 6.5 & 68.2 & 0 & 30.4 \\
\hline ZONE 5 & 65.7 & 0 & 14.1 & 65.7 & 0 & 14.1 & 65.7 & 0 & 14.1 \\
\hline ZONE 6 & 62.9 & 0 & 17.8 & 62.9 & 0 & 17.8 & 62.9 & 0 & 17.8 \\
\hline ZONE 7 & 78.9 & 0.1 & 14.1 & 78.9 & 0.1 & 14.1 & 78.9 & 0.1 & 14.1 \\
\hline ZONE 8 & 52.2 & 0 & 13.0 & 52.2 & 0 & 13.0 & 52.2 & 0 & 13.0 \\
\hline ZONE 9 & 75.6 & 1.0 & 12.5 & 75.6 & 1.0 & 12.5 & 75.6 & 1.0 & 12.5 \\
\hline ZONE 10 & 62.3 & 0.5 & 16.7 & 62.3 & 0.5 & 16.7 & 5.2 & 80.3 & 0 \\
\hline ZONE 11 & 83.0 & 0.3 & 8.7 & 83.0 & 0.3 & 8.7 & 63.2 & 26.9 & 1.8 \\
\hline ZONE 12 & 56.0 & 0.8 & 17.2 & 56.0 & 0.7 & 17.2 & 17.8 & 58.0 & 3.6 \\
\hline ZONE 13 & 33.9 & 0.7 & 24.2 & 33.9 & 0.7 & 24.2 & 33.9 & 0.7 & 24.2 \\
\hline TOTAL & 67.7 & 0.3 & 14.4 & 54.1 & 13.3 & 12.9 & 54.1 & 13.3 & 12.9 \\
\hline
\end{tabular}


under the three different land use patterns:

$$
\begin{aligned}
& \text { Loading }=\quad \sum_{\mathrm{U}=\mathrm{A}}^{\mathrm{E}}\left(\text { area }_{\mathrm{u}}{ }^{*} \mathrm{load}_{\mathrm{u}}\right) \text { in } \mathrm{kg} / \mathrm{yr} \\
& \text { where; } \\
& \begin{array}{ll}
\mathrm{U}=\text { land use; } & \mathrm{A}=\text { high developed; } \\
\mathrm{B} & =\text { low developed; } \\
\mathrm{C} & =\text { grassland; } \\
\mathrm{D} & =\text { cropland; } \\
\mathrm{E} & =\text { forest. }
\end{array}
\end{aligned}
$$

"Loading" (Eq.1) was calculated from the range of land use runoff loads found in Table 7 and the land use distributions for each zone calculated from the Coast Watch data. The use of a range of land use runoff values results in high and low values for the loading index, as well as for the throughput (Equation 3) and percent load retained (Equation 4) indices.

$$
\text { Burial }=\left(\text { burial }_{\text {phosphorus }} *_{\text {area }_{\text {wetland }}}\right) \text { in } \mathrm{kg} / \mathrm{yr}
$$

"Burial" (Eq.2) was assumed to represent the wetland's actual absolute long term phosphorus retention(burial). Phosphorus retention rates, needed for the burial calculation, were assigned to wetlands in all three of the above land use scenarios (existing, top , bottom), using an average of the values calculated (Table 3) of 2.8 $\mathrm{kg} / \mathrm{ha} / \mathrm{yr}$.

$$
\text { Throughput }=(\text { Loading })-(\text { Burial }) \text { in } \mathrm{kg} / \mathrm{yr}
$$

"Throughput" (Eq.3) is a simple estimate of the total phosphorus budget for the zone in question.

$$
\text { Percent Load Retained }=[(\text { Burial }) /(\text { Loading })] 100=\%
$$

"Percent load retained" (Eq.4) was taken as an indicator of the relative retention of the 
wetland, based on it opportunity (Loading), and its capabilities (Burial).

\subsubsection{Cumulative Throughput}

The cumulative throughput for the entire study area was calculated and compared to measured water quality data for the sole purpose of ascertaining the validity of the runoff loads and wetland total phosphorus burial rates used. The purpose of this exercise was simply to test the range of values used for total phosphorus runoff loads and wetland total phosphorus retention rates. This was done by back calculating from measured total phosphorus water concentrations to estimate the runoff load in kilograms per year that would account for the measured values. An average value taken from a ten year record of total phosphorus water samples from the Chesapeake Bay Tributary Monitoring Program database (1984-1994) West Point station was used :

$$
C=(F P)\left(a_{2} / a_{1}\right)
$$

where:

$\mathrm{F}=$ average flow of the York River (1/s) (USDC, 1985);

$\mathrm{P}=$ total particulate phosphorus concentration (mg/) (VA DEQ, 1984-94);

$a_{1}=$ York River watershed area (van der Leeden, 1993);

$a_{2}=$ area of study watersheds;

$\mathrm{C}=$ predicted load from area equal to study watershed to account for measured total phosphorus in water column,

\subsection{RESULTS AND DISCUSSION}

\subsubsection{Watershed Analysis}

The first three principal component axes explained $85 \%$ of the between wetland variation in landscape positioning. The first axis represents high loading of three variables; grasslands and croplands area within the wetland's primary watershed, as well as 
the ratio of wetland to watershed area. The second axis represents high loading for two variables; wetland and forested land areas within the watershed. The third axis represents high loading for two variables; development, and distance from the Mattaponi River (Table 9).

The stepwise regression found no significance between total phosphorus retention or loss rate and any of the three principal component axes. This would suggest that the landscape variables analyzed can not account for individual wetland total phosphorus retention. The land use and landscape variables chosen are not adequate to predict wetland total phosphorus retention.

The actual contribution of a wetland to the watershed is a function of a combination of the wetland's burial abilities, the land use located within the wetland's watershed, as well as the relative size of the wetland to the watershed. While a wetland may have a high burial (absolute retention), its relative efficiency (relative retention) may turn out to be low. Wetland site $\mathrm{E}$ has a high burial $(7.8 \mathrm{~kg} / \mathrm{yr})$, and a low percent retention range (25-76\%). In contrast, site $\mathrm{D}$, has a low burial $(2.1 \mathrm{~kg} / \mathrm{yr})$, but a very high relative retention (100\%) likely due to a low loading (Table 10). This demonstrates how important it is to evaluate wetland function on both an absolute and a relative scale. While a wetland may not appear to be contributing much to the watershed, or to water quality maintenance on one scale, it may seem irreplaceable on the other scale.

\subsubsection{Cumulative Watershed Analysis}

Total cumulative watershed throughput was found to be nearly equal within watersheds of similiar land use proportions. However, total phosphorus throughput at a 


\section{TABLE 9}

First three principal component axes and the variables with which they were significantly correlated $(p<0.002)$.

\begin{tabular}{llll}
\hline $\begin{array}{l}\text { PC } \\
\text { AXIS }\end{array}$ & VARIABLES & INTERPRETATION & \\
\hline 1 & $\begin{array}{l}\text { grass } \\
\text { crop } \\
\text { ratio* }\end{array}$ & open areas & $42 \%$ \\
2 & $\begin{array}{l}\text { forest } \\
\text { wetland }\end{array}$ & undisturbed areas & $27 \%$ \\
3 & developed & developed/high use areas & $16 \%$ \\
\hline & $\begin{array}{l}\text { Total Variance accounted for } \\
*\end{array}$ & $85 \%$ \\
** mattaponi $=$ distance by straight line vector from the Mattaponi River
\end{tabular}




\section{TABLE 10}

Description of sample areas estimated contribution to total phosphorus retention. Site refers to samples A-N, located on Figure 1. BURIAL (Eq.3) is the wetland phosphorus retention rate multiplied by the wetland area. TP LOADING (Eq.4) is the predicted amount of total phosphorus runoff from the wetland primary watershed. High and low values reflect the range of run-off coefficients used from Table 7. The low and high values from loading are carried through the last two calculations. THROUGHPUT (Eq.5) is the difference between the total phosphorus loading and burial. PERCENT LOAD RETAINED (Eq.6) is a measure of the relative efficiency of the wetland and is equal to the burial divided by loading.

\begin{tabular}{|l||l||l|l||c|c||c|c|}
\hline \multicolumn{1}{|c||}{ SITE } & \multicolumn{1}{|c||}{$\begin{array}{l}\text { BURIAL } \\
(\mathrm{kg} / \mathrm{yr})\end{array}$} & \multicolumn{2}{|c||}{$\begin{array}{l}\text { TP LOADING } \\
(\mathrm{kg} / \mathrm{yr})\end{array}$} & \multicolumn{2}{c||}{$\begin{array}{c}\text { THROUGHPUT } \\
(\mathrm{kg} / \mathrm{yr})\end{array}$} & \multicolumn{2}{c|}{$\begin{array}{c}\text { \% LOAD } \\
\text { RETAINED }\end{array}$} \\
\hline & & low & high & low & high & low & high \\
\hline A & 5.9 & 7.3 & 20.0 & 1.5 & 14.1 & 80 & 29 \\
\hline B & 51.0 & 3.6 & 10.6 & 0 & 0 & 100 & 100 \\
\hline C & 0.5 & 0.4 & 1.8 & 0 & 1.2 & 100 & 31 \\
\hline D & 2.1 & 0.3 & 1.2 & 0 & 0 & 100 & 100 \\
\hline E & 7.8 & 10.2 & 30.6 & 2.5 & 22.9 & 76 & 25 \\
\hline F & 4.0 & 11.6 & 30.4 & 7.6 & 26.4 & 34 & 13 \\
\hline G & 0.9 & 4.2 & 10.4 & 3.3 & 9.5 & 22 & 9 \\
\hline H & 7.2 & 11.9 & 31.1 & 4.7 & 23.9 & 61 & 23 \\
\hline I & 8.8 & 12.7 & 33.6 & 3.9 & 24.8 & 100 & 100 \\
\hline J & 3.9 & 0.2 & 1.0 & 0 & 0 & 100 & 100 \\
\hline K & 0.6 & 17.0 & 45.4 & 16.4 & 44.8 & 4 & 1 \\
\hline L & 0.4 & 18.3 & 49.6 & 17.8 & 49.1 & 2 & 1 \\
\hline M & 3.0 & 21.0 & 55.8 & 18.0 & 52.8 & 15 & 5 \\
\hline N & 0.1 & 13.9 & 36.3 & 13.8 & 36.2 & 1 & 0 \\
\hline & & & & & & & \\
\hline
\end{tabular}


given location within a watershed varied greatly between watersheds with different land use distributions (Figure 6). Development near the headwaters may allow for greater opportunity for phosphorus filtration before entering the rivers, but, it results in increased total phosphorus concentrations throughout the entire watershed. In contrast, development of the lower regions of a watershed results in a lower total phosphorus concentration in the upper reaches of the watershed, but offers less opportunity for wetland retention, with the cumulative throughput being slightly higher than for headwater development.

To take advantage of this feature, created wetlands could be strategically sited in the lower regions of a watershed in order to protect water quality (Detenbeck et al. 1993). Furthermore, watershed water quality may be better protected by strategically placing created wetlands immediately downstream from any land use with significant phosphorus run-off loadings. This suggests that land development and water quality issues should be managed in a comprehensive manner and not as separate entities.

\subsubsection{Cumulative Throughput}

The estimated cumulative throughput for the entire study area, based on surface water flow was found to range from 0 to $3,000 \mathrm{~kg} / \mathrm{yr}$. The total phosphorus load for a watershed of equal size to the study area calculated from total phosphorus concentrations in the top of the water column was $3,300(\mathrm{SD}=200) \mathrm{kg} / \mathrm{yr}$. Some of the difference may be accounted for through other total phosphorus sources/sinks such as groundwater flow and atmospheric deposition. However, surface water flow is believed to be the primary path of phosphorus flow (Mitsch et al. 1993). This result indicates that at a 
Figure 6. Cumulative watershed throughput, by zone, for Corbin Creek watershed. Results for three different land use distributions:1) current land use; 2) development near the headwaters (top); and 3) development near the lower regions of the watershed (bottom). Top and bottom have the same proportion of land uses, with different distributions. Throughput was calculated using Eq.5. High and low ends of the bars represent the results using the high and low ends of the run-off load ranges found in Table 7. The middle bar represents the average of the high and low results. 

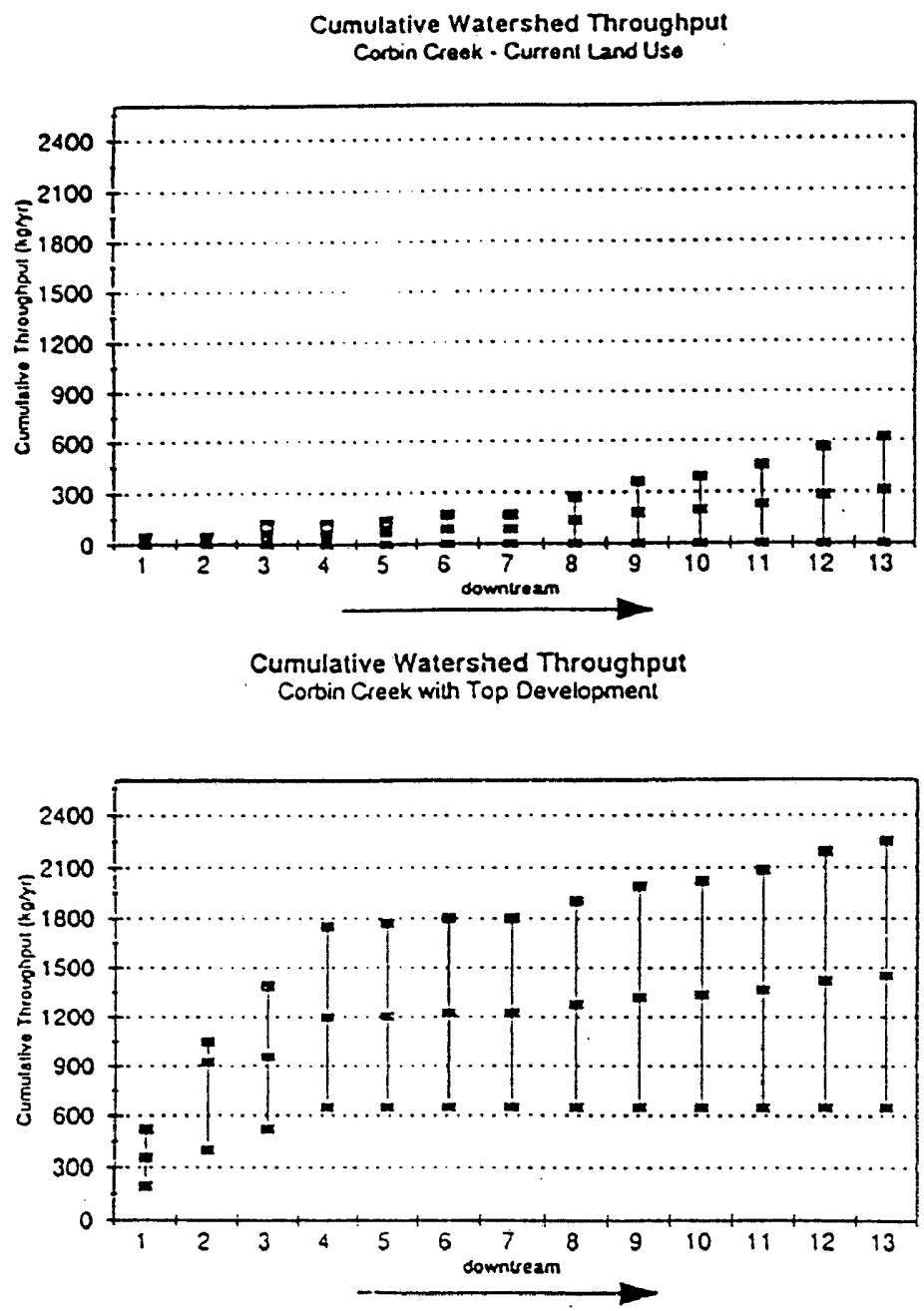

Cumlativs watershed Throughput Corbin Creek with Bottom Development

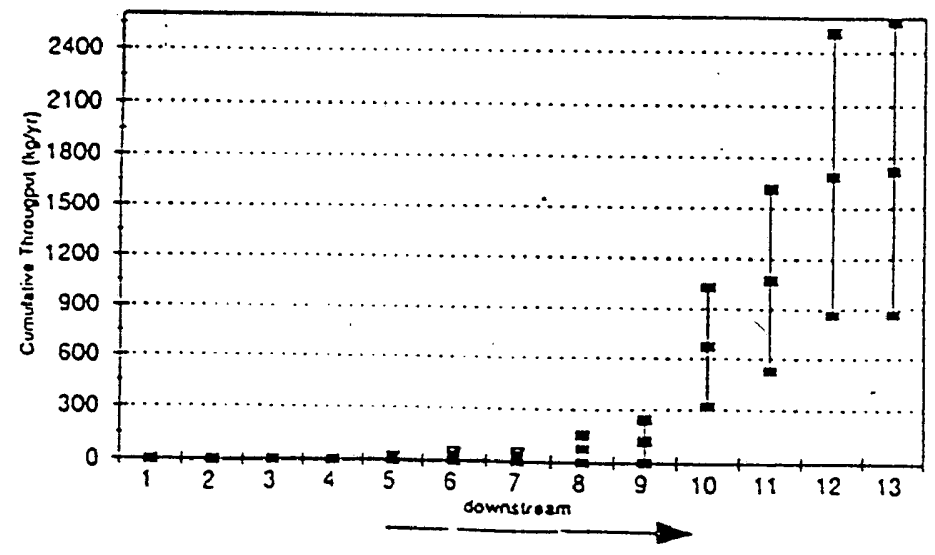


minimum, the range of run-off loads and the land use extents used were relatively accurate.

\subsection{CONCLUSIONS/IMPLICATIONS FOR WATERSHED MANAGEMENT}

Watershed structure needs to be a major consideration of wetland management. Critical parameters include wetland location, extent and upland land use distributions. A relationship may exist between dominant land uses located in a wetland's primary watershed and wetland total phosphorus retention/loss functioning. This may allow prediction of wetland total phosphorus retention based on easily attainable indicators such as wetland extent and surrounding land use. Wetland management and mitigation practices incorporating an analysis of surrounding land use influences on phosphorus inputs into wetlands would result in more accurate estimates of wetland functioning. This type of approach may not only maximize the use of the natural phosphorus retention role of wetlands within the landscape, but also increase flexibility of land use planning with the use of GIS.

Wetland and developed land use locations within the watershed were found to be important in cumulative watershed total phosphorus retention/loss and, more importantly, in the distribution of total phosphorus throughputs within the watershed. Development of the upper reaches of the watershed allow greater opportunity for phosphorus filtration before entering the rivers, however, this pattern results in increased total phosphorus concentrations throughout the entire watershed. In contrast, development of the lower regions of a watershed leaves the upper reaches of the watershed pristine, but offers less opportunity for wetland retention, with the cumulative throughput being slightly higher 
than for top development. Overall, development in the lower reaches of watersheds may be the best management option. This does demonstrate that management of wetlands, land use development and water quality are all inter-related. Mitigation and creation of wetlands without also considering the effects of upland land uses, and proposed changes in upland land uses on the entire watershed compromise effective management of water quality.

The estimated throughput of total phosphorus from the York River watersheds was within the same order of magnitude as the predicted throughput based on measured water quality data. This suggests that the run-off load coefficients and estimated total phosphorus retention rates used in this study were appropriate. This creates an opportunity to approximate total phosphorus budgets for watersheds in the coastal plain of Virginia with relatively simpole measures of land use patterns. 


\subsection{GENERAL SUMMARY}

Wetlands located near West Point, VA accumulate sediment (3.0-5.6 mm/yr) and retain total phosphorus $\left(0.05-1.30 \mathrm{~g} \mathrm{TP} / \mathrm{m}^{2} / \mathrm{yr}\right)$ over the long term. Total phosphorus retention did not correlate with wetland type, as defined by Cowardin et al. (1979). Only diked wetlands were found to have higher than average phosphorus retention rates, most likely from increased water retention times. This has significant consequences for current wetland management practices which essentially attempt to equate functional values with wetland type. Management by wetland type fails to fully account for all the losses that are being incurred in the wetland resources, by not incorporating all variables that influence wetland functioning.

Results did show a relationship between total phosphorus retention and wetland location as defined by stream order (Strahler 1960), suggesting that wetland positioning and surrounding land use may be important factors influencing wetland total phosphorus retention. This supports the idea that wetlands are not isolated systems and their functioning is a reflection of both internal characteristics such as soil chemistry, vegetation and hydrology, as well as location influences such as surrounding land uses, upland total phosphorus run-off loads, and wetland position (Craft et al. 1993; Detenbeck et al. 1993). Actual amounts of total phosphorus retained will be influenced by the phosphorus loading the wetland receives, as determined by surrounding and land and land use, as well as wetland soil characteristics and hydrology. This suggests that wetland mitigation and creation policies should incorporate a landscape level analysis as opposed to site by site evaluations. A landscape analysis which includes an analysis of the surrounding land uses 
and resultant phosphorus run-off loads would greatly increase the accuracy and integrity of current wetland management.

The distribution of wetlands and upland land uses was found to influence the distribution of total phosphorus concentrations within the watershed. Development of the upper reaches of a watershed may result in high phosphorus levels throughout the remainder of the watershed. This is a result of high phosphorus inputs to the headwaters. In contrast, placement of wetlands in the upper reaches of a watershed, along with development in lower regions may maintain a fairly low level of phosphorus concentrations throughout the watershed. Watershed water quality may be better maintained in the long run by strategically placing created wetlands directly downstream from land uses with significant total phosphorus run-off. As well, development in the lower reaches of a watershed may help in maintaining higher water quality standards.

This study also suggested several other areas to explore using the concept of landscape ecology, watershed analysis and GIS technology. While total phosphorus may be considered an analog for most urban pollutants, nitrogen, is not included. Analyzing watershed nitrogen budgets would be valuable as excess nitrogen is problematic in Chesapeake Bay waters. As well, coupling watershed level studies with physical transport models such as the universal soil loss equation could provide some added insight into wetland functioning within the landscape. Ultimately, the ability to predict changes in nutrient and pollutant throughput within a watershed under different development and wetland mitigation scenarios would be extremely valuable for water quality maintenance. 
APPENDIX A. Nutrient Inputs - Summary

A number of different pathways exist for nutrient inputs into wetlands. These include geologic inputs, which could include rock weathering; biologic inputs such as photosynthesis or biotic transport; or hydrologic inputs determined by the flow of water through the wetland. However, it is generally believed that nutrient and sediment inputs into wetlands are dominated by the driving force of hydrology (Mitsch et al. 1993). Peterjohn and Correll (1984) concluded in a study of landscape nutrient budgets, that surface water flow was the dominant phosphorus wetland input. Furthermore, relationships between land use practices and water quality indicate a strong correlation between land use and nutrient runoff loads (for eg. Beulac et al. 1982; Loehr 1974). Other sources of non point loading that may be of interest include groundwater flows and atmospheric deposition.

Several comprehensive watershed studies calculate land-use nutrient runoff loads (Correll et al. 1977; Beulac et al. 1982; Loehr 1974). Nutrient runoff loads vary not only with land-use but have also been correlated with rainfall, soil type, watershed slope, variety of topography, seasonal effects and climate (Schueler \& Bley 1987; Mitsch et al. 1993). The Virginia/Chesapeake Bay Best Management Practice (BMP's) handbook (Schueler \& Bley 1987) calculates loading rates based first on upland land uses and secondly by rainfall and soil type.

Extensive studies in the Rhode River watershed on Maryland's western shore of the Chesapeake Bay represent an effort to relate discharge characteristics to land use by analyzing runoff waters for suspended particulate, nutrient, cation, herbicide and bacterial 
parameters (Correll 1977). Results indicate that land use in the Rhode River subwatersheds is the most important factor controlling nutrient loads in runoff waters.

Other sources of phosphorus loadings that may be important include groundwater and atmospheric deposition. Generally, while phosphorus can be a groundwater pollutant of concern, it is typically not considered a major contaminant source. It is believed to be easily retained in surface and subsurface soils due to chemical change and adsorption (Carter et al. 1987). At any one time, a major proportion of the phosphorus in wetlands is tied up in organic litter and peat and in inorganic sediments. Overall, phosphorus cycling, especially in mineral soils tends to follow sediment pathways as opposed to groundwater flows (Mitsch et al. 1993).

Additions of phosphorus through precipitation are variable but extremely dilute (Mitsch et al. 1993). Human influence on chemicals in precipitation (acid rain), has been relatively significant and is most likely responsible for the biggest variations in spatial distribution of chemical concentrations in precipitation. However, phosphorus is generally not a chemical of concern in acid rain. Moreover, studies limited to smaller areas tend to have a relatively homogeneous pattern of atmospheric inputs. 


\section{APPENDIX B. Sedimentation Studies in Wetlands - Summary}

A number of different approaches exist to measure marsh sedimentation rates. These methods cover time scales ranging from periods of just weeks to several centuries (Reed 1987). The earliest studies involved the use of artificial marker horizons (Richards 1934; Steers 1938,1948). Since then, numerous studies have used similar methods of creating marker beds with brick dust or aluminum glitter scattered on the sediment (Reed 1989). Artificial marker horizons such as brick dust or glitter scattered on the sediment may be used to measure marsh accretion in the $0.5-10$ year time scale (Reed 1989). These methods tend to be sensitive to sporadic sedimentation or erosion events such as storms and are essentially limited to measuring seasonal/annual variability (Stoddart et al. 1989). Furthermore, there have been problems with the labeled horizon sinking into the mud, being washed away by rain, eroded by waves or bioturbated beyond recognition (Richard 1978).

More recently, the use of radioisotopes has provided a reliable method for longer term sedimentation studies (Kearny et al. 1983; DeLaune et al. 1989; Stoddart et al. 1989) The two most commonly used are ${ }^{210} \mathrm{~Pb}$ and ${ }^{137} \mathrm{Cs} .{ }^{210} \mathrm{~Pb}$ is a naturally occurring isotope and can be used to date sediments from the last 80 - 150 years (Kearny et al. 1983; DeLaune et al. 1989). In contrast, ${ }^{137} \mathrm{Cs}$ is a fallout product of atmospheric nuclear weapons and reactors. ${ }^{137} \mathrm{Cs}$ from nuclear weapons fallout can be differentiated from ${ }^{137} \mathrm{Cs}$ of reactor origin by the absence of cobalt which is also a reactor product. The appearance in the sediment profile of ${ }^{137} \mathrm{Cs}$ from nuclear weapons corresponds to the initiation of nuclear weapons testing in 1953 with a significant peak in 1963, marking the peak of nuclear 
weapon testing in the United States (Pennington et al. 1973). Thus, ${ }^{137} \mathrm{Cs}$ is appropriate for sedimentation on an approximate 30 year time scale.

Researchers have found both ${ }^{210} \mathrm{~Pb}$ and ${ }^{137} \mathrm{Cs}$ to be in good agreement for eg. Craft et al. 1993; DeLaune et al. 1989; Orson et al. 1990). For both radioisotopes, dramatic changes in land use may influence the results of the dating techniques by causing large changes in sedimentation in the watershed. Thus, it is important to determine not only the time scale in which you are interested, but the appropriate time scale based on periods of land use change in the watershed of interest. In many rural areas, dramatic changes in land use occurred around the early to mid twentieth century. ${ }^{137} \mathrm{Cs}$ provides a good method for short term averages where little change has occurred in the last 30 years. Migration of the isotope has been identified as a possible problem in using ${ }^{137} \mathrm{Cs}$. ${ }^{137} \mathrm{Cs}$ is strongly adsorbed on clay and organic particles, uptake by vegetation is low, and diffusion is usually limited (Ritchie et al. 1990). Furthermore, adsorption has been inversely related to grain size and salinity (Brickman 1978; Warinner 1962). Thus, the technique is useful and reliable in sedimentary environments high in clay and silt and low in salinity. ${ }^{137} \mathrm{Cs}$ has been used successfully in numerous marsh studies ( eg. Craft et al. 1993; McIntyre et al. 1991; Orson et al. 1990; Thom 1992). However, even in studies where ${ }^{137} \mathrm{Cs}$ was "successfully" used, few investigators were able to achieve over a $50 \%$ success rate in obtaining clean profiles (for eg. Craft et al. 1993). The presence of numerous organisms, humans and other perturbances to the wetland often have adverse effects on attempts to obtain undisturbed thirty year sedimentation records. 
APPENDIX C. Grain size and total phosphorus analysis results

Results of total phosphorus (TP) analysis and grain size analysis by site. Site refers to sample location, located on Figurel.

\begin{tabular}{|l|l|l|l|l|l|l|}
\hline SITE & $\begin{array}{c}\text { DEPTH } \\
(\mathrm{cm})\end{array}$ & \%GRAVEL & \%SAND & \%SILT & \%CLAY & $\begin{array}{c}\text { [TP] } \\
\text { (mg TP/g sed) }\end{array}$ \\
\hline A & 3 & 0 & 91.6 & 3.1 & 5.3 & 0.321 \\
\hline A & 6 & 0 & 99.8 & 0 & 0.2 & 0.169 \\
\hline A & 9 & 0 & 92.0 & 4.2 & 3.8 & 0.314 \\
\hline A & 12 & 0.1 & 94.3 & 2.4 & 3.2 & 0.199 \\
\hline A & 15 & 0.5 & 90.3 & 4.5 & 4.7 & 0.188 \\
\hline A & 18 & 0 & 91.7 & 3.4 & 4.9 & 0.277 \\
\hline A & 21 & 0 & 91.9 & 2.7 & 5.4 & 0.283 \\
\hline A & 24 & 0.1 & 91.4 & 5 & 3.5 & 0.41 \\
\hline A & 27 & 0.1 & 88.0 & 7.1 & 4.8 & 0.354 \\
\hline A & 30 & 0 & 92.1 & 3.1 & 4.8 & 0.222 \\
\hline A & 33 & 0.2 & 92.7 & 3.1 & 4.0 & 0.178 \\
\hline B & 3 & 43.2 & 40.9 & 11.1 & 4.8 & 1.016 \\
\hline B & 6 & 17.9 & 19.9 & 23.7 & 38.5 & 0.888 \\
\hline B & 9 & 1.5 & 12.1 & 27.8 & 58.6 & 0.916 \\
\hline B & 12 & 0 & 3.6 & 24.2 & 72.2 & 0.728 \\
\hline B & 15 & 0 & 4.4 & 31.6 & 64.0 & 0.701 \\
\hline B & 18 & 0 & 2.0 & 27.4 & 70.6 & 0.615 \\
\hline B & 21 & 0 & 0 & 48.8 & 51.2 & 0.616 \\
\hline B & 24 & 0 & 0 & 51.4 & 48.6 & 0.656 \\
\hline B & 27 & 0 & 4.3 & 33.8 & 61.9 & 0.856 \\
\hline B & 30 & 0 & 0 & 30.0 & 7.0 & 0.535 \\
\hline B & 33 & 0 & 1.9 & 42.2 & 55.9 & 0.529 \\
\hline
\end{tabular}




\begin{tabular}{|l|l|l|l|l|l|l|}
\hline SITE & $\begin{array}{c}\text { DEPTH } \\
(\mathrm{cm})\end{array}$ & \%GRAVEL & \%SAND & \%SIT & \%CLAY & $\begin{array}{c}\text { [TP] } \\
(\mathrm{mg} \mathrm{TP/g} \mathrm{sed})\end{array}$ \\
\hline C & 3 & 0 & 53.4 & 37.9 & 8.7 & 0.227 \\
\hline C & 9 & 0.2 & 80.8 & 15.3 & 3.7 & 0.097 \\
\hline C & 15 & 0 & 49.3 & 39.4 & 11.3 & 0.157 \\
\hline C & 18 & 0 & 53.9 & 39.7 & 6.4 & 0.165 \\
\hline C & 21 & 0.4 & 65.9 & 26.2 & 7.5 & 0.135 \\
\hline C & 27 & 1.3 & 77.7 & 15.6 & 5.4 & 0.079 \\
\hline C & 30 & 1.6 & 62.1 & 27.8 & 8.5 & 0.122 \\
\hline D & 3 & 4.5 & 79.8 & 9.5 & 6.2 & 0.157 \\
\hline D & 6 & 3.8 & 73.5 & 15.3 & 7.4 & 0.165 \\
\hline D & 9 & 3 & 69.9 & 18.2 & 9.0 & 0.175 \\
\hline D & 12 & 1.4 & 72.0 & 18.7 & 7.9 & 0.183 \\
\hline D & 15 & 2.9 & 74.2 & 12.4 & 10.5 & 0.189 \\
\hline D & 18 & 1.9 & 67.5 & 16.3 & 14.3 & 0.153 \\
\hline D & 21 & 7.0 & 76.3 & 7.0 & 9.7 & 0.124 \\
\hline D & 24 & 5.1 & 83.2 & 6.6 & 5.1 & 0.114 \\
\hline D & 27 & 3.0 & 72.3 & 17.0 & 7.7 & 0.105 \\
\hline E & 3 & 0 & 80.1 & 10.7 & 9.2 & 0.231 \\
\hline E & 6 & 0 & 86.0 & 8.5 & 5.5 & 0.231 \\
\hline E & 9 & 0 & 85.1 & 8.4 & 6.5 & 0.261 \\
\hline E & 12 & 0 & 64.8 & 21.4 & 13.8 & 0.499 \\
\hline E & 15 & 0 & 82.6 & 11.0 & 6.4 & 0.348 \\
\hline E & 18 & 0 & 73.6 & 16.8 & 9.6 & 0.319 \\
\hline E & 21 & 0 & 86.0 & 8.5 & 5.5 & 0.119 \\
\hline E & 24 & 0 & 85.7 & 9.3 & 5.0 & 0.147 \\
\hline F & 3 & 5.2 & 56.7 & 6.9 & 31.2 & 0.600 \\
\hline & & & & & & \\
\hline
\end{tabular}




\begin{tabular}{|l|l|l|l|l|l|l|}
\hline SITE & $\begin{array}{l}\text { DEPTH } \\
(\mathrm{cm})\end{array}$ & \%GRAVEL & \%SAND & \%SILT & \%CLAY & $\begin{array}{c}\text { [TP] } \\
\text { (mg TP/g sed) }\end{array}$ \\
\hline F & 6 & 0 & 75.5 & 10.7 & 13.8 & 0.390 \\
\hline F & 9 & 0 & 82.3 & 9.8 & 7.9 & 0.272 \\
\hline F & 12 & 0.2 & 85.2 & 7.4 & 7.2 & 0.123 \\
\hline F & 15 & 1.1 & 84.2 & 8.5 & 6.2 & 0.115 \\
\hline F & 21 & 0.9 & 80.4 & 10.3 & 8.4 & 0.086 \\
\hline F & 24 & 0.4 & 76.1 & 12.6 & 10.9 & 0.109 \\
\hline F & 27 & 2.9 & 97.1 & 0 & 0 & 0.101 \\
\hline F & 30 & 1.0 & 79.6 & 9.6 & 9.8 & 0.097 \\
\hline F & 33 & 1.5 & 98.5 & 0 & 0 & 0.078 \\
\hline G & 3 & 6.8 & 93.2 & 0 & 0 & 0.597 \\
\hline G & 6 & 0 & 89.3 & 10.7 & 0 & 0.39 \\
\hline G & 9 & 0.3 & 89.3 & 10.4 & 0 & 0.343 \\
\hline G & 12 & 6.1 & 93.9 & 0 & 0 & 0.135 \\
\hline G & 15 & 4.6 & 95.4 & 0 & 0 & 0.085 \\
\hline G & 18 & 21.9 & 67.8 & 3.7 & 6.6 & 0.043 \\
\hline G & 21 & 20.0 & 80.0 & 0 & 0 & 0.034 \\
\hline G & 24 & 0.6 & 99.4 & 0 & 0 & 0.035 \\
\hline G & 27 & 24.2 & 75.8 & 0 & 0 & 0.084 \\
\hline H & 3 & 0 & 100.0 & 0 & 0 & 1.109 \\
\hline H & 6 & 0 & 100.0 & 0 & 0 & 0.409 \\
\hline H & 9 & 0.5 & 99.5 & 0 & 0 & 0.186 \\
\hline H & 12 & 0.6 & 81.4 & 11.5 & 6.5 & 0.085 \\
\hline H & 15 & 3.7 & 96.3 & 0 & 0 & 0.105 \\
\hline H & 18 & 0 & 5.8 & 67.5 & 26.7 & 0.325 \\
\hline H & 21 & 4.3 & 58.8 & 27.2 & 9.7 & 0.128 \\
\hline
\end{tabular}




\begin{tabular}{|l|l|l|l|l|l|l|}
\hline SITE & $\begin{array}{l}\text { DEPTH } \\
(\mathrm{cm})\end{array}$ & \%GRAVEL & \%SAND & \%SILT & \%CLAY & $\begin{array}{c}{[\mathrm{TP}]} \\
\text { (mg TP/g sed) }\end{array}$ \\
\hline $\mathrm{H}$ & 24 & 2.5 & 58.7 & 36.5 & 2.3 & 0.136 \\
\hline $\mathrm{H}$ & 27 & 0 & 100.0 & 0 & 0 & 0.447 \\
\hline $\mathrm{H}$ & 30 & 0 & 12.5 & 87.5 & 0 & 0.512 \\
\hline $\mathrm{H}$ & 33 & 0 & 18.9 & 72.8 & 8.3 & 0.439 \\
\hline $\mathrm{I}$ & 3 & 0 & 90.0 & 3.9 & 6.1 & 0.161 \\
\hline $\mathrm{I}$ & 6 & 0 & 76.0 & 14.9 & 9.1 & 0.438 \\
\hline $\mathrm{I}$ & 9 & 0 & 73.5 & 13.9 & 12.6 & 0.388 \\
\hline $\mathrm{I}$ & 12 & 0 & 59.8 & 18.8 & 21.4 & 0.427 \\
\hline $\mathrm{I}$ & 15 & 0 & 80.8 & 8.9 & 10.3 & 0.262 \\
\hline $\mathrm{I}$ & 18 & 0 & 84.6 & 6.7 & 8.7 & 0.119 \\
\hline $\mathrm{I}$ & 21 & 0.1 & 81.3 & 7.8 & 10.8 & 0.11 \\
\hline $\mathrm{I}$ & 24 & 0 & 86.7 & 5.4 & 7.9 & 0.102 \\
\hline $\mathrm{J}$ & 3 & 0 & 98.2 & 0.7 & 1.1 & 0.091 \\
\hline $\mathrm{J}$ & 6 & 0 & 96.6 & 2.0 & 1.4 & 0.073 \\
\hline $\mathrm{J}$ & 9 & 0 & 85.6 & 7.8 & 6.6 & 0.197 \\
\hline $\mathrm{J}$ & 12 & 0 & 81.2 & 11.0 & 7.8 & 0.469 \\
\hline $\mathrm{J}$ & 15 & 0 & 93.2 & 4.0 & 2.8 & 0.845 \\
\hline $\mathrm{J}$ & 18 & 0 & 98.2 & 0 & 1.8 & 0.097 \\
\hline $\mathrm{J}$ & 21 & 0 & 93.9 & 4.1 & 2.0 & 0.103 \\
\hline $\mathrm{J}$ & 24 & 0 & 82.5 & 8.9 & 8.6 & 0.537 \\
\hline $\mathrm{J}$ & 27 & 0 & 82.8 & 13.0 & 4.2 & 0.299 \\
\hline $\mathrm{J}$ & 30 & 0 & 97.3 & 2.2 & 0.5 & 0.108 \\
\hline $\mathrm{K}$ & 3 & 0 & 73.3 & 18.8 & 7.9 & 0.198 \\
\hline $\mathrm{K}$ & 6 & 0 & 73.5 & 16.7 & 9.8 & 0.175 \\
\hline $\mathrm{K}$ & 9 & 0 & 76.6 & 15.6 & 7.8 & 0.117 \\
\hline
\end{tabular}




\begin{tabular}{|l|l|l|l|l|l|l|}
\hline SITE & $\begin{array}{l}\text { DEPTH } \\
(\mathrm{cm})\end{array}$ & $\begin{array}{l}\text { \%GRAVEL } \\
\text { \%SAND }\end{array}$ & \%SIL & \%CLAY & $\begin{array}{c}\text { [TP] } \\
\text { (mg TP/g sed) }\end{array}$ \\
\hline K & 12 & 2.1 & 79.9 & 11.9 & 6.1 & 0.116 \\
\hline K & 15 & 0.5 & 84.8 & 9.2 & 5.5 & 0.038 \\
\hline K & 18 & 0 & 79.0 & 12.4 & 8.6 & 0.037 \\
\hline K & 21 & 0.1 & 69.2 & 20.8 & 9.9 & 0.084 \\
\hline L & 3 & 0.2 & 60.8 & 27.3 & 11.7 & 0.174 \\
\hline L & 6 & 0.3 & 66.3 & 20.2 & 13.2 & 0.146 \\
\hline L & 9 & 1.3 & 76.4 & 15.4 & 6.9 & 0.083 \\
\hline L & 12 & 0 & 79.7 & 12.9 & 7.4 & 0.063 \\
\hline L & 15 & 0.3 & 86.4 & 9.3 & 4.0 & 0.046 \\
\hline L & 18 & 0.1 & 75.9 & 17.2 & 6.8 & 0.078 \\
\hline L & 21 & 1.7 & 76.8 & 14.0 & 7.5 & 0.058 \\
\hline L & 24 & 0.3 & 88.1 & 6.8 & 4.8 & 0.05 \\
\hline L & 27 & 0.2 & 77.8 & 14.8 & 7.2 & 0.064 \\
\hline L & 30 & 0.2 & 74.9 & 17.3 & 7.6 & 0.081 \\
\hline M & 3 & 0 & 86.9 & 9.8 & 3.3 & 0.078 \\
\hline M & 6 & 1.6 & 91.5 & 3.9 & 3.0 & 0.037 \\
\hline M & 9 & 2.6 & 85.5 & 7.8 & 4.1 & 0.028 \\
\hline M & 12 & 0.1 & 80.1 & 14.0 & 5.8 & 0.059 \\
\hline M & 15 & 0 & 84.8 & 10.8 & 4.4 & 0.085 \\
\hline M & 18 & 0 & 88.2 & 7.2 & 4.6 & 0.040 \\
\hline M & 21 & 1.1 & 85.4 & 9.3 & 4.2 & 0.057 \\
\hline M & 24 & 0.7 & 72.5 & 22.2 & 4.6 & 0.092 \\
\hline M & 27 & 3.0 & 73.7 & 17.6 & 5.7 & 0.085 \\
\hline M & 30 & 0.7 & 74.1 & 19.7 & 5.5 & 0.098 \\
\hline N & 3 & 0 & 80.2 & 19.8 & 0 & 0.178 \\
\hline
\end{tabular}




\begin{tabular}{|l|l|l|l|l|l|l|}
\hline SITE & $\begin{array}{l}\text { DEPTH } \\
(\mathrm{cm})\end{array}$ & \%GRAVEL & \%SAND & \%SILT & \%CLAY & $\begin{array}{c}{[\mathrm{TP}]} \\
(\mathrm{mg} \text { TP/g sed })\end{array}$ \\
\hline $\mathrm{N}$ & 6 & 2.3 & 90.4 & 6.0 & 1.3 & 0.196 \\
\hline $\mathrm{N}$ & 9 & 3.4 & 92.8 & 2.9 & 0.9 & 0.040 \\
\hline $\mathrm{N}$ & 12 & 0.8 & 99.2 & 0 & 0 & 0.023 \\
\hline $\mathrm{N}$ & 15 & 0 & 91.0 & 7.6 & 1.4 & 0.042 \\
\hline $\mathrm{N}$ & 18 & 0 & 97.5 & 2.5 & 0 & 0.072 \\
\hline $\mathrm{N}$ & 21 & 10.8 & 88.0 & 0.9 & 0.3 & 0.039 \\
\hline $\mathrm{N}$ & 24 & 4.5 & 92.8 & 1.6 & 1.1 & 0.029 \\
\hline $\mathrm{N}$ & 27 & 0.8 & 94.9 & 3.4 & 0.9 & 0.052 \\
\hline $\mathrm{N}$ & 30 & 1.2 & 94.7 & 3.0 & 1.1 & 0.053 \\
\hline $\mathrm{N}$ & 33 & 1.0 & 96.5 & 1.3 & 1.2 & 0.036 \\
\hline
\end{tabular}


APPENDIX D. ${ }^{137}$ Cs Results

Summary of results of ${ }^{137} \mathrm{Cs}$ in counts per minute(cpm) with associated errors. In bold, are the peak, 1963 concentrations used for calculations of sediment accumulation rates. Site refers to sample site located on Figure 1.

\begin{tabular}{|c|c|c|c|c|c|c|c|c|}
\hline \multirow{2}{*}{\begin{tabular}{|l|} 
DEPTH \\
$(\mathrm{cm})$ \\
\end{tabular}} & \multicolumn{2}{|c|}{ SITE L } & \multicolumn{2}{|c|}{ SITE I } & \multicolumn{2}{|c|}{ SITE D } & \multicolumn{2}{|c|}{ SITE F } \\
\hline & CPM & error & CPM & error & CPM & error & CPM & error \\
\hline $\begin{array}{l}1 \\
2\end{array}$ & 0.195 & 0.31 & 0.169 & 0.27 & 0.170 & 0.37 & 0.235 & 0.24 \\
\hline $\begin{array}{l}3 \\
4\end{array}$ & $\begin{array}{l}0.157 \\
0.176\end{array}$ & $\begin{array}{l}0.45 \\
0.35\end{array}$ & 0.153 & 0.29 & 0.155 & 0.23 & 0.262 & 0.37 \\
\hline 5 & 0.128 & 0.28 & 0.164 & 0.30 & 0.080 & 0.34 & 0.256 & 0.25 \\
\hline 6 & 0.282 & 0.28 & & & & & & \\
\hline 7 & 0.219 & 0.23 & 0.233 & 0.21 & 0.057 & 0.50 & 0.224 & 0.16 \\
\hline 8 & 0.290 & 0.27 & & & & & 0.203 & 0.20 \\
\hline 9 & 0.349 & 0.19 & 0.383 & 0.18 & 0.218 & 0.31 & 0.235 & 0.31 \\
\hline 10 & 0.253 & 0.31 & 0.327 & 0.15 & 0.297 & 0.18 & & \\
\hline 11 & 0.150 & 0.32 & 0.223 & 0.24 & 0.337 & 0.18 & 0.297 & 0.22 \\
\hline 12 & 0.240 & 0.26 & & & 0.253 & 0.23 & & \\
\hline 13 & 0.253 & 0.31 & 0.417 & 0.17 & 0.228 & 0.22 & 0.284 & 0.23 \\
\hline 14 & 0.23 & 0.20 & 0.083 & 0.56 & 0.204 & 0.23 & & \\
\hline 15 & $(+)$ & & 0.185 & 0.27 & $(+)$ & & 0.247 & 0.22 \\
\hline 16 & 0.092 & 0.46 & 0.076 & 0.35 & & & & \\
\hline 17 & 0.186 & 0.36 & 0.05 & & (+) & & 0.388 & 0.14 \\
\hline 18 & & & & & & & 0.376 & 0.13 \\
\hline 19 & 0.143 & 0.35 & & & 0 & & 0.340 & 0.18 \\
\hline $\begin{array}{l}20 \\
21\end{array}$ & 0 & & & & 0 & & 0125 & 025 \\
\hline 22 & & & & & & & & \\
\hline 23 & & & & & & & $(+)$ & \\
\hline
\end{tabular}


APPENDIX E. Summary of land use areas for wetland sample watersheds. Site refers to wetland samples A-N, located on Figure 1.

\begin{tabular}{|c|c|c|c|c|c|c|c|}
\hline$\frac{\text { LANDUSE }}{\text { SITE }}$ & $\mathrm{HIGH}^{*}$ & LOW* & GRASS & CROP & FOREST & $\begin{array}{l}\text { WETLAND } \\
\text { AREA }\end{array}$ & $\begin{array}{l}\text { TOTAL } \\
\text { AREA }\end{array}$ \\
\hline $\begin{array}{c}\text { A hectares } \\
\%\end{array}$ & $\begin{array}{l}0 \\
0\end{array}$ & $\begin{array}{l}0 \\
0\end{array}$ & $\begin{array}{l}1.5 \\
8.8\end{array}$ & $\begin{array}{l}5.7 \\
33.9\end{array}$ & $\begin{array}{l}8.4 \\
50.0\end{array}$ & $\begin{array}{l}1.4 \\
8.3\end{array}$ & 16.8 \\
\hline $\begin{array}{c}\text { B hectares } \\
\%\end{array}$ & $\begin{array}{l}0 \\
0\end{array}$ & $\begin{array}{l}1.3 \\
5.2\end{array}$ & $\begin{array}{l}1.3 \\
5.2\end{array}$ & $\begin{array}{l}0.9 \\
3.7\end{array}$ & $\begin{array}{l}15.5 \\
64.5\end{array}$ & $\begin{array}{l}5.1 \\
21.4\end{array}$ & 24.1 \\
\hline $\begin{array}{c}\text { hectares } \\
\%\end{array}$ & $\begin{array}{l}0 \\
0\end{array}$ & $\begin{array}{l}0 \\
0\end{array}$ & $\begin{array}{l}0 \\
0\end{array}$ & $\begin{array}{l}0 \\
0\end{array}$ & $\begin{array}{l}7.0 \\
95.9\end{array}$ & $\begin{array}{l}0.3 \\
4.1\end{array}$ & 7.3 \\
\hline $\begin{array}{c}\text { D hectares } \\
\%\end{array}$ & $\begin{array}{l}0 \\
0\end{array}$ & $\begin{array}{l}0 \\
0\end{array}$ & $\begin{array}{l}0 \\
0\end{array}$ & $\begin{array}{l}0 \\
0\end{array}$ & $\begin{array}{l}4.7 \\
78.1\end{array}$ & $\begin{array}{l}1.3 \\
21.7\end{array}$ & 6.0 \\
\hline $\begin{array}{c}\text { E hectares } \\
\%\end{array}$ & $\begin{array}{l}0 \\
0\end{array}$ & $\begin{array}{l}0 \\
0\end{array}$ & $\begin{array}{l}9.6 \\
14.8\end{array}$ & $\begin{array}{l}4.0 \\
6.1\end{array}$ & $\begin{array}{l}49.3 \\
75.8\end{array}$ & $\begin{array}{l}2.1 \\
3.3\end{array}$ & 65.0 \\
\hline $\begin{array}{c}F \quad \text { hectares } \\
\%\end{array}$ & $\begin{array}{l}1.0 \\
3.1\end{array}$ & $\begin{array}{l}6.0 \\
19.0\end{array}$ & $\begin{array}{l}4.3 \\
13.7\end{array}$ & $\begin{array}{l}1.7 \\
5.4\end{array}$ & $\begin{array}{l}16.2 \\
51.1\end{array}$ & $\begin{array}{l}2.5 \\
7.7\end{array}$ & 31.7 \\
\hline $\begin{array}{c}\text { G hectares } \\
\%\end{array}$ & $\begin{array}{l}0.1 \\
0.7\end{array}$ & $\begin{array}{l}0.5 \\
4.4\end{array}$ & $\begin{array}{l}7.4 \\
61.7\end{array}$ & $\begin{array}{l}1.1 \\
9.2\end{array}$ & $\begin{array}{l}1.9 \\
15.8\end{array}$ & $\begin{array}{l}1.0 \\
8.2\end{array}$ & 12.0 \\
\hline $\begin{array}{c}H \text { hectares } \\
\%\end{array}$ & $\begin{array}{l}1.0 \\
3.1\end{array}$ & $\begin{array}{l}6.2 \\
20.0\end{array}$ & $\begin{array}{l}4.5 \\
14.5\end{array}$ & $\begin{array}{l}1.7 \\
5.5\end{array}$ & $\begin{array}{l}16.3 \\
52.1\end{array}$ & $\begin{array}{l}1.5 \\
4.8\end{array}$ & 31.1 \\
\hline $\begin{array}{c}\text { I hectares } \\
\%\end{array}$ & $\begin{array}{l}1.0 \\
2.4\end{array}$ & $\begin{array}{l}5.5 \\
13.2 \\
\end{array}$ & $\begin{array}{l}4.9 \\
11.8\end{array}$ & $\begin{array}{l}2.6 \\
6.3\end{array}$ & $\begin{array}{l}22.1 \\
53.1\end{array}$ & $\begin{array}{l}5.5 \\
13.2\end{array}$ & 41.0 \\
\hline $\begin{array}{c}\text { J hectares } \\
\%\end{array}$ & $\begin{array}{l}0 \\
0\end{array}$ & $\begin{array}{l}0 \\
0\end{array}$ & $\begin{array}{l}0 \\
0\end{array}$ & $\begin{array}{l}0 \\
0\end{array}$ & $\begin{array}{l}4.0 \\
85.1 \\
\end{array}$ & $\begin{array}{l}0.7 \\
14.9 \\
\end{array}$ & 4.7 \\
\hline $\begin{array}{c}\mathrm{K} \text { hectares } \\
\%\end{array}$ & $\begin{array}{l}0 \\
0 \\
\end{array}$ & $\begin{array}{l}0 \\
0\end{array}$ & $\begin{array}{l}10.2 \\
25.5 \\
\end{array}$ & $\begin{array}{l}11.7 \\
29.3 \\
\end{array}$ & $\begin{array}{l}17.4 \\
43.6 \\
\end{array}$ & $\begin{array}{l}0.6 \\
1.6 \\
\end{array}$ & 39.9 \\
\hline $\begin{array}{c}\text { L hectares } \\
\%\end{array}$ & $\begin{array}{l}0 \\
0 \\
\end{array}$ & $\begin{array}{l}0 \\
0 \\
\end{array}$ & $\begin{array}{l}2.9 \\
7.9 \\
\end{array}$ & $\begin{array}{l}14.8 \\
40.3 \\
\end{array}$ & $\begin{array}{l}18.5 \\
50.6 \\
\end{array}$ & $\begin{array}{l}0.4 \\
1.2 \\
\end{array}$ & 36.6 \\
\hline $\begin{array}{c}\text { M hectares } \\
\%\end{array}$ & $\begin{array}{l}0 \\
0\end{array}$ & $\begin{array}{l}0.1 \\
0.2 \\
\end{array}$ & $\begin{array}{l}9.3 \\
22.6\end{array}$ & $\begin{array}{l}15.7 \\
38.4\end{array}$ & $\begin{array}{l}14.0 \\
34.1\end{array}$ & $\begin{array}{l}1.9 \\
4.7\end{array}$ & 41.0 \\
\hline $\begin{array}{c}\mathrm{N} \text { hectares } \\
\%\end{array}$ & $\begin{array}{l}0 \\
0\end{array}$ & $\begin{array}{l}0.1 \\
0.4\end{array}$ & $\begin{array}{l}5.9 \\
30.5\end{array}$ & $\begin{array}{l}10.8 \\
56.1\end{array}$ & $\begin{array}{l}2.4 \\
12.6\end{array}$ & $\begin{array}{l}0.1 \\
0.4\end{array}$ & 19.3 \\
\hline
\end{tabular}

* developed - high $=$ commercial; low $=$ residential 
APPENDIX F. Summary of watershed land use areas for the entire study area near West Point, VA in hectares. Watershed is located on Figure 1.

\begin{tabular}{|c|c|c|c|c|c|c|c|}
\hline$\frac{\text { LANDUSE }}{\text { ZONE }}$ & $\mathrm{HIGH}^{*}$ & LOW* & GRASS & CROP & FOREST & $\begin{array}{l}\text { WETLAND } \\
\text { AREA }\end{array}$ & $\begin{array}{l}\text { TOTAL } \\
\text { AREA }\end{array}$ \\
\hline $\begin{array}{c}1 \text { hectares } \\
\%\end{array}$ & $\begin{array}{l}0 \\
0\end{array}$ & $\begin{array}{l}0.4 \\
0.2\end{array}$ & $\begin{array}{l}9.3 \\
3.9\end{array}$ & $\begin{array}{l}13.7 \\
5.7\end{array}$ & $\begin{array}{l}196.0 \\
81.7\end{array}$ & $\begin{array}{l}20.6 \\
8.5\end{array}$ & 240.0 \\
\hline $\begin{array}{c}2 \text { hectares } \\
\%\end{array}$ & $\begin{array}{l}0 \\
0\end{array}$ & $\begin{array}{l}0 \\
0\end{array}$ & $\begin{array}{l}0 \\
0\end{array}$ & $\begin{array}{l}0 \\
0\end{array}$ & $\begin{array}{l}183.5 \\
83.5\end{array}$ & $\begin{array}{l}36.3 \\
16.5\end{array}$ & 219.8 \\
\hline $\begin{array}{c}3 \text { hectares } \\
\%\end{array}$ & $\begin{array}{l}0 \\
0\end{array}$ & $\begin{array}{l}0 \\
0\end{array}$ & $\begin{array}{l}19.1 \\
13.2\end{array}$ & $\begin{array}{l}42.1 \\
29.1\end{array}$ & $\begin{array}{l}57.7 \\
39.9\end{array}$ & $\begin{array}{l}25.7 \\
17.8\end{array}$ & 144.6 \\
\hline $\begin{array}{c}4 \text { hectares } \\
\%\end{array}$ & $\begin{array}{l}0 \\
0\end{array}$ & $\begin{array}{l}0 \\
0\end{array}$ & $\begin{array}{l}2.3 \\
1.3 \\
\end{array}$ & $\begin{array}{l}0 \\
0 \\
\end{array}$ & $\begin{array}{l}147.0 \\
86.4 \\
\end{array}$ & $\begin{array}{l}20.9 \\
12.3\end{array}$ & 170.2 \\
\hline $\begin{array}{c}5 \text { hectares } \\
\%\end{array}$ & $\begin{array}{l}0 \\
0\end{array}$ & $\begin{array}{l}0 \\
0\end{array}$ & $\begin{array}{l}18.4 \\
10.8\end{array}$ & $\begin{array}{l}16.1 \\
9.4\end{array}$ & $\begin{array}{l}112.1 \\
65.7\end{array}$ & $\begin{array}{l}24.0 \\
14.1\end{array}$ & 170.6 \\
\hline $\begin{array}{c}6 \text { hectares } \\
\%\end{array}$ & $\begin{array}{l}0 \\
0\end{array}$ & $\begin{array}{l}0.1 \\
0\end{array}$ & $\begin{array}{l}3.1 \\
1.9\end{array}$ & $\begin{array}{l}29.6 \\
17.4\end{array}$ & $\begin{array}{l}107.1 \\
62.9\end{array}$ & $\begin{array}{l}30.3 \\
17.8\end{array}$ & 170.2 \\
\hline $\begin{array}{c}7 \text { hectares } \\
\%\end{array}$ & $\begin{array}{l}0 \\
0\end{array}$ & $\begin{array}{l}0.4 \\
0.1 \\
\end{array}$ & $\begin{array}{l}17.4 \\
5.9\end{array}$ & $\begin{array}{l}2.8 \\
1.0\end{array}$ & $\begin{array}{l}231.1 \\
78.9\end{array}$ & $\begin{array}{l}41.27 \\
14.1\end{array}$ & 292.8 \\
\hline $\begin{array}{c}8 \text { hectares } \\
\%\end{array}$ & $\begin{array}{l}0 \\
0\end{array}$ & $\begin{array}{l}0 \\
0\end{array}$ & $\begin{array}{l}32.3 \\
14.2\end{array}$ & $\begin{array}{l}46.7 \\
20.6\end{array}$ & $\begin{array}{l}118.3 \\
52.2\end{array}$ & $\begin{array}{l}29.5 \\
13.0\end{array}$ & 226.8 \\
\hline $\begin{array}{c}9 \text { hectares } \\
\%\end{array}$ & $\begin{array}{l}0.2 \\
0\end{array}$ & $\begin{array}{l}0.8 \\
1.0\end{array}$ & $\begin{array}{l}9.1 \\
1.6\end{array}$ & $\begin{array}{l}59.0 \\
10.2\end{array}$ & $\begin{array}{l}437.2 \\
75.6\end{array}$ & $\begin{array}{l}72.1 \\
12.5\end{array}$ & 578.4 \\
\hline $\begin{array}{c}10 \text { hectares } \\
\%\end{array}$ & $\begin{array}{l}0.2 \\
0.1\end{array}$ & $\begin{array}{l}1.4 \\
0.4\end{array}$ & $\begin{array}{l}27.6 \\
8.9\end{array}$ & $\begin{array}{l}36.1 \\
11.6\end{array}$ & $\begin{array}{l}194.0 \\
62.3\end{array}$ & $\begin{array}{l}52.1 \\
16.7\end{array}$ & 311.4 \\
\hline $\begin{array}{c}11 \text { hectares } \\
\%\end{array}$ & $\begin{array}{l}0 \\
0\end{array}$ & $\begin{array}{l}1.6 \\
0.3\end{array}$ & $\begin{array}{l}25.5 \\
4.3\end{array}$ & $\begin{array}{l}21.9 \\
3.7\end{array}$ & $\begin{array}{l}487.9 \\
83.0\end{array}$ & $\begin{array}{l}51.1 \\
8.7\end{array}$ & 588.0 \\
\hline $\begin{array}{c}12 \text { hectares } \\
\%\end{array}$ & $\begin{array}{l}0 \\
0\end{array}$ & $\begin{array}{l}3.2 \\
0.8\end{array}$ & $\begin{array}{l}39.0 \\
8.7\end{array}$ & $\begin{array}{l}77.7 \\
17.3\end{array}$ & $\begin{array}{l}250.8 \\
56.0\end{array}$ & $\begin{array}{l}77.2 \\
17.2\end{array}$ & 447.9 \\
\hline $\begin{array}{c}13 \text { hectares } \\
\%\end{array}$ & $\begin{array}{l}0 \\
0\end{array}$ & $\begin{array}{l}2.1 \\
0.7\end{array}$ & $\begin{array}{l}64.6 \\
19.7\end{array}$ & $\begin{array}{l}70.3 \\
21.5\end{array}$ & $\begin{array}{l}110.9 \\
33.9\end{array}$ & $\begin{array}{l}79.1 \\
24.2\end{array}$ & 327.0 \\
\hline $\begin{array}{c}14 \text { hectares } \\
\%\end{array}$ & $\begin{array}{l}0 \\
0\end{array}$ & $\begin{array}{l}0.1 \\
0\end{array}$ & $\begin{array}{l}209.6 \\
21.3\end{array}$ & $\begin{array}{l}58.3 \\
5.9\end{array}$ & $\begin{array}{l}654.1 \\
66.4\end{array}$ & $\begin{array}{l}63.4 \\
6.4\end{array}$ & 985.5 \\
\hline
\end{tabular}




\begin{tabular}{|c|c|c|c|c|c|c|c|}
\hline $\begin{array}{l}\text { LAND USE } \\
\text { ZONE }\end{array}$ & $\mathrm{HIGH}^{*}$ & LOW* & GRASS & CROP & FOREST & $\begin{array}{l}\text { WETLAND } \\
\text { AREA }\end{array}$ & $\begin{array}{l}\text { TOTAL } \\
\text { AREA }\end{array}$ \\
\hline $\begin{array}{c}15 \text { hectares } \\
\%\end{array}$ & $\begin{array}{l}0.1 \\
0\end{array}$ & $\begin{array}{l}0.4 \\
0.1\end{array}$ & $\begin{array}{l}31.2 \\
7.3\end{array}$ & $\begin{array}{l}54.1 \\
12.6\end{array}$ & $\begin{array}{l}307.2 \\
71.6\end{array}$ & $\begin{array}{l}36.1 \\
8.4\end{array}$ & 429.1 \\
\hline $\begin{array}{c}16 \text { hectares } \\
\%\end{array}$ & $\begin{array}{l}0.1 \\
0\end{array}$ & $\begin{array}{l}0.2 \\
0\end{array}$ & $\begin{array}{l}14.9 \\
3.7\end{array}$ & $\begin{array}{l}16.8 \\
4.1\end{array}$ & $\begin{array}{l}342.0 \\
83.6\end{array}$ & $\begin{array}{l}35.2 \\
8.6\end{array}$ & 409.2 \\
\hline $\begin{array}{c}17 \text { hectares } \\
\%\end{array}$ & $\begin{array}{l}0.4 \\
0.1\end{array}$ & $\begin{array}{l}50.1 \\
8.2\end{array}$ & $\begin{array}{l}19.0 \\
3.1\end{array}$ & $\begin{array}{l}18.9 \\
3.1\end{array}$ & $\begin{array}{l}478.5 \\
78.3\end{array}$ & $\begin{array}{l}44.1 \\
7.2\end{array}$ & 611.0 \\
\hline $\begin{array}{c}18 \text { hectares } \\
\%\end{array}$ & $\begin{array}{l}7.2 \\
1.3\end{array}$ & $\begin{array}{l}1.2 \\
0.2\end{array}$ & $\begin{array}{l}61.1 \\
9.9\end{array}$ & $\begin{array}{l}121.7 \\
19.7\end{array}$ & $\begin{array}{l}357.3 \\
57.9\end{array}$ & $\begin{array}{l}68.7 \\
11.1\end{array}$ & 617.2 \\
\hline $\begin{array}{c}19 \text { hectares } \\
\%\end{array}$ & $\begin{array}{l}0.1 \\
0\end{array}$ & $\begin{array}{l}0 \\
0\end{array}$ & $\begin{array}{l}25.8 \\
8.0\end{array}$ & $\begin{array}{l}37.0 \\
11.6\end{array}$ & $\begin{array}{l}204.6 \\
64.7\end{array}$ & $\begin{array}{l}51.8 \\
16.2\end{array}$ & 319.3 \\
\hline $\begin{array}{c}20 \text { hectares } \\
\%\end{array}$ & $\begin{array}{l}0.1 \\
0 \\
\end{array}$ & $\begin{array}{l}5.3 \\
0.9\end{array}$ & $\begin{array}{l}108.0 \\
15.7 \\
\end{array}$ & $\begin{array}{l}119.9 \\
17.4\end{array}$ & $\begin{array}{l}348.3 \\
46.0\end{array}$ & $\begin{array}{l}137.7 \\
20.0\end{array}$ & 719.3 \\
\hline $\begin{array}{c}21 \text { hectares } \\
\%\end{array}$ & $\begin{array}{l}117.3 \\
10.4\end{array}$ & $\begin{array}{l}101.9 \\
9.1\end{array}$ & $\begin{array}{l}139.9 \\
12.5\end{array}$ & $\begin{array}{l}123.6 \\
11.0\end{array}$ & $\begin{array}{l}255.8 \\
22.8\end{array}$ & $\begin{array}{l}384.5 \\
34.2\end{array}$ & 1123.0 \\
\hline TOTAL & $\begin{array}{l}125.7 \\
1.4\end{array}$ & $\begin{array}{l}169.2 \\
1.9\end{array}$ & $\begin{array}{l}877.2 \\
9.6\end{array}$ & $\begin{array}{l}966.4 \\
10.6\end{array}$ & $\begin{array}{l}5581.3 \\
61.3\end{array}$ & $\begin{array}{l}1381.5 \\
15.2\end{array}$ & 9101.3 \\
\hline
\end{tabular}

* developed - high $=$ commercial

- low = residential 
APPENDIX G. Summary of current watershed land use areas for Corbin Creek watershed by zone, in hectares.

\begin{tabular}{|c|c|c|c|c|c|c|c|}
\hline$\frac{\text { LANDUSE }}{\text { ZONE }}$ & $\mathrm{HIGH}^{*}$ & LOW* & GRASS & CROP & FOREST & $\begin{array}{l}\text { WETLAND } \\
\text { AREA }\end{array}$ & $\begin{array}{r}\text { TOTAL } \\
\text { AREA }\end{array}$ \\
\hline $\begin{array}{c}1 \text { hectares } \\
\%\end{array}$ & $\begin{array}{l}0 \\
0\end{array}$ & $\begin{array}{l}0.4 \\
0.2\end{array}$ & $\begin{array}{l}9.3 \\
3.9 \\
\end{array}$ & $\begin{array}{l}13.8 \\
5.7 \\
\end{array}$ & $\begin{array}{l}196.0 \\
81.7\end{array}$ & $\begin{array}{l}20.6 \\
8.5\end{array}$ & 240.0 \\
\hline $\begin{array}{c}2 \text { hectares } \\
\%\end{array}$ & $\begin{array}{l}0 \\
0\end{array}$ & $\begin{array}{l}0 \\
0\end{array}$ & $\begin{array}{l}0 \\
0\end{array}$ & $\begin{array}{l}0 \\
0\end{array}$ & $\begin{array}{l}183.5 \\
83.5\end{array}$ & $\begin{array}{l}36.3 \\
16.5\end{array}$ & 219.8 \\
\hline $\begin{array}{c}3 \text { hectares } \\
\%\end{array}$ & $\begin{array}{l}0 \\
0\end{array}$ & $\begin{array}{l}0 \\
0\end{array}$ & $\begin{array}{l}19.1 \\
13.2\end{array}$ & $\begin{array}{l}42.1 \\
29.1\end{array}$ & $\begin{array}{l}57.7 \\
39.9\end{array}$ & $\begin{array}{l}25.7 \\
17.8\end{array}$ & 144.6 \\
\hline $\begin{array}{c}4 \text { hectares } \\
\%\end{array}$ & $\begin{array}{l}0 \\
0\end{array}$ & $\begin{array}{l}0 \\
0\end{array}$ & $\begin{array}{l}2.3 \\
1.3\end{array}$ & $\begin{array}{l}0 \\
0\end{array}$ & $\begin{array}{l}147.0 \\
86.4\end{array}$ & $\begin{array}{l}20.9 \\
12.3\end{array}$ & 170.2 \\
\hline $\begin{array}{c}5 \text { hectares } \\
\%\end{array}$ & $\begin{array}{l}0 \\
0\end{array}$ & $\begin{array}{l}0 \\
0\end{array}$ & $\begin{array}{l}18.4 \\
10.8 \\
\end{array}$ & $\begin{array}{l}16.1 \\
9.4\end{array}$ & $\begin{array}{l}112.1 \\
65.7\end{array}$ & $\begin{array}{l}24.0 \\
14.1\end{array}$ & 170.6 \\
\hline $\begin{array}{c}6 \text { hectares } \\
\%\end{array}$ & $\begin{array}{l}0 \\
0\end{array}$ & $\begin{array}{l}0.1 \\
0\end{array}$ & $\begin{array}{l}3.1 \\
1.9\end{array}$ & $\begin{array}{l}29.6 \\
17.4 \\
\end{array}$ & $\begin{array}{l}107.1 \\
62.9\end{array}$ & $\begin{array}{l}30.3 \\
17.8\end{array}$ & 170.2 \\
\hline $\begin{array}{c}7 \text { hectares } \\
\%\end{array}$ & $\begin{array}{l}0 \\
0\end{array}$ & $\begin{array}{l}0.4 \\
0.1 \\
\end{array}$ & $\begin{array}{l}17.4 \\
5.9\end{array}$ & $\begin{array}{l}2.8 \\
1.0\end{array}$ & $\begin{array}{l}231.1 \\
78.9\end{array}$ & $\begin{array}{l}41.2 \\
14.1\end{array}$ & 292.9 \\
\hline $\begin{array}{c}8 \text { hectares } \\
\%\end{array}$ & $\begin{array}{l}0 \\
0\end{array}$ & $\begin{array}{l}0 \\
0 \\
\end{array}$ & $\begin{array}{l}32.3 \\
14.2 \\
\end{array}$ & $\begin{array}{l}46.7 \\
20.6 \\
\end{array}$ & $\begin{array}{l}118.3 \\
52.2 \\
\end{array}$ & $\begin{array}{l}29.5 \\
13.0 \\
\end{array}$ & 226.8 \\
\hline $\begin{array}{c}9 \text { hectares } \\
\%\end{array}$ & $\begin{array}{l}0.2 \\
0 \\
\end{array}$ & $\begin{array}{l}0.8 \\
1.0\end{array}$ & $\begin{array}{l}9.1 \\
1.6\end{array}$ & $\begin{array}{l}59.0 \\
10.2 \\
\end{array}$ & $\begin{array}{l}437.2 \\
75.6 \\
\end{array}$ & $\begin{array}{l}72.1 \\
12.5 \\
\end{array}$ & 578.4 \\
\hline $\begin{array}{c}10 \text { hectares } \\
\%\end{array}$ & $\begin{array}{l}0.2 \\
0.1\end{array}$ & $\begin{array}{l}1.4 \\
0.4\end{array}$ & $\begin{array}{l}27.6 \\
8.9 \\
\end{array}$ & $\begin{array}{l}36.1 \\
11.6\end{array}$ & $\begin{array}{l}194.0 \\
62.3 \\
\end{array}$ & $\begin{array}{l}52.1 \\
16.7\end{array}$ & 311.4 \\
\hline $\begin{array}{c}11 \text { hectares } \\
\%\end{array}$ & $\begin{array}{l}0 \\
0\end{array}$ & $\begin{array}{l}1.6 \\
0.3\end{array}$ & $\begin{array}{l}25.5 \\
4.3 \\
\end{array}$ & $\begin{array}{l}21.9 \\
3.7\end{array}$ & $\begin{array}{l}487.9 \\
83.0\end{array}$ & $\begin{array}{l}51.1 \\
8.7\end{array}$ & 588.0 \\
\hline $\begin{array}{c}12 \text { hectares } \\
\%\end{array}$ & $\begin{array}{l}0 \\
0\end{array}$ & $\begin{array}{l}3.2 \\
0.8\end{array}$ & $\begin{array}{l}39.0 \\
8.7\end{array}$ & $\begin{array}{l}77.7 \\
17.3\end{array}$ & $\begin{array}{l}250.8 \\
56.0\end{array}$ & $\begin{array}{l}77.2 \\
17.2\end{array}$ & 447.9 \\
\hline $\begin{array}{c}13 \text { hectares } \\
\%\end{array}$ & $\begin{array}{l}0 \\
0\end{array}$ & $\begin{array}{l}2.1 \\
0.7\end{array}$ & $\begin{array}{l}64.6 \\
19.7\end{array}$ & $\begin{array}{l}70.3 \\
21.5\end{array}$ & $\begin{array}{l}110.9 \\
33.9\end{array}$ & $\begin{array}{l}79.1 \\
24.2\end{array}$ & 327.0 \\
\hline TOTAL & $\begin{array}{l}0.4 \\
0\end{array}$ & $\begin{array}{l}10.0 \\
0.3\end{array}$ & $\begin{array}{l}267.7 \\
6.9\end{array}$ & $\begin{array}{l}416.1 \\
10.7\end{array}$ & $\begin{array}{l}2633.5 \\
67.7\end{array}$ & $\begin{array}{l}560.1 \\
14.4\end{array}$ & 3887.7 \\
\hline
\end{tabular}

* developed - high $=$ commercial; low $=$ residential 
APPENDIX H. Summary of watershed land use areas for Corbin Creek watershed by zone, after simulated TOP development, in hectares.

\begin{tabular}{|c|c|c|c|c|c|c|c|}
\hline$\frac{\text { LANDUSE }}{\text { ZONE }}$ & $\mathrm{HIGH}^{*}$ & LOW* & GRASS & CROP & FOREST & $\begin{array}{l}\text { WETLAND } \\
\text { AREA }\end{array}$ & $\begin{array}{r}\text { TOTAL } \\
\text { AREA }\end{array}$ \\
\hline $\begin{array}{c}1 \text { hectares } \\
\%\end{array}$ & $\begin{array}{l}38.3 \\
16.0\end{array}$ & $\begin{array}{l}148.8 \\
62.0\end{array}$ & $\begin{array}{l}0 \\
0\end{array}$ & $\begin{array}{l}13.8 \\
5.8\end{array}$ & $\begin{array}{l}28.7 \\
12.0\end{array}$ & $\begin{array}{l}10.4 \\
4.3\end{array}$ & 240.0 \\
\hline $\begin{array}{c}2 \text { hectares } \\
\%\end{array}$ & $\begin{array}{l}48.3 \\
22.0\end{array}$ & $\begin{array}{l}153.2 \\
69.7\end{array}$ & $\begin{array}{l}0 \\
0\end{array}$ & $\begin{array}{l}0 \\
0\end{array}$ & $\begin{array}{l}10.3 \\
4.7\end{array}$ & $\begin{array}{l}8.0 \\
3.6\end{array}$ & 219.8 \\
\hline $\begin{array}{c}3 \text { hectares } \\
\%\end{array}$ & $\begin{array}{l}57.6 \\
39.8\end{array}$ & $\begin{array}{l}73.4 \\
50.8\end{array}$ & $\begin{array}{l}0 \\
0\end{array}$ & $\begin{array}{l}0 \\
0\end{array}$ & $\begin{array}{l}0 \\
0\end{array}$ & $\begin{array}{l}13.6 \\
9.4\end{array}$ & 144.6 \\
\hline $\begin{array}{c}4 \text { hectares } \\
\%\end{array}$ & $\begin{array}{l}32.4 \\
19.0\end{array}$ & $\begin{array}{l}110.3 \\
64.8\end{array}$ & $\begin{array}{l}0 \\
0\end{array}$ & $\begin{array}{l}0 \\
0\end{array}$ & $\begin{array}{l}16.4 \\
9.6\end{array}$ & $\begin{array}{l}11.1 \\
6.5\end{array}$ & 170.2 \\
\hline $\begin{array}{c}5 \text { hectares } \\
\%\end{array}$ & $\begin{array}{l}0 \\
0\end{array}$ & $\begin{array}{l}0 \\
0\end{array}$ & $\begin{array}{l}18.4 \\
10.8\end{array}$ & $\begin{array}{l}16.1 \\
9.4\end{array}$ & $\begin{array}{l}112.1 \\
65.7\end{array}$ & $\begin{array}{l}24.0 \\
14.1\end{array}$ & 170.6 \\
\hline $\begin{array}{c}6 \text { hectares } \\
\%\end{array}$ & $\begin{array}{l}0 \\
0\end{array}$ & $\begin{array}{l}0.1 \\
0\end{array}$ & $\begin{array}{l}3.1 \\
1.9\end{array}$ & $\begin{array}{l}29.6 \\
17.4\end{array}$ & $\begin{array}{l}107.1 \\
62.9\end{array}$ & $\begin{array}{l}30.3 \\
17.8\end{array}$ & 170.2 \\
\hline $\begin{array}{c}7 \text { hectares } \\
\%\end{array}$ & $\begin{array}{l}0 \\
0\end{array}$ & $\begin{array}{l}0.4 \\
0.1\end{array}$ & $\begin{array}{l}17.4 \\
5.9\end{array}$ & $\begin{array}{l}2.8 \\
1.0\end{array}$ & $\begin{array}{l}231.1 \\
78.9\end{array}$ & $\begin{array}{l}41.1 \\
14.1\end{array}$ & 292.8 \\
\hline $\begin{array}{c}8 \text { hectares } \\
\%\end{array}$ & $\begin{array}{l}0 \\
0\end{array}$ & $\begin{array}{l}0 \\
0\end{array}$ & $\begin{array}{l}32.3 \\
14.2\end{array}$ & $\begin{array}{l}46.7 \\
20.6 \\
\end{array}$ & $\begin{array}{l}118.3 \\
52.2\end{array}$ & $\begin{array}{l}29.5 \\
13.0\end{array}$ & 226.8 \\
\hline $\begin{array}{c}9 \text { hectares } \\
\%\end{array}$ & $\begin{array}{l}0.2 \\
0 \\
\end{array}$ & $\begin{array}{l}0.8 \\
1.0\end{array}$ & $\begin{array}{l}9.1 \\
1.6\end{array}$ & $\begin{array}{l}59.0 \\
10.2\end{array}$ & $\begin{array}{l}437.2 \\
75.6\end{array}$ & $\begin{array}{l}72.1 \\
12.5\end{array}$ & 578.4 \\
\hline $\begin{array}{c}10 \text { hectares } \\
\%\end{array}$ & $\begin{array}{l}0.2 \\
0.1 \\
\end{array}$ & $\begin{array}{l}1.4 \\
0.4 \\
\end{array}$ & $\begin{array}{l}27.6 \\
8.9 \\
\end{array}$ & $\begin{array}{l}36.1 \\
11.6 \\
\end{array}$ & $\begin{array}{l}194.0 \\
62.3 \\
\end{array}$ & $\begin{array}{l}52.1 \\
16.7\end{array}$ & 311.4 \\
\hline $\begin{array}{c}11 \text { hectares } \\
\%\end{array}$ & $\begin{array}{l}0 \\
0\end{array}$ & $\begin{array}{l}1.6 \\
0.3\end{array}$ & $\begin{array}{l}25.5 \\
4.3\end{array}$ & $\begin{array}{l}21.9 \\
3.7\end{array}$ & $\begin{array}{l}487.9 \\
83.0\end{array}$ & $\begin{array}{l}51.1 \\
8.7\end{array}$ & 588.0 \\
\hline $\begin{array}{c}12 \text { hectares } \\
\%\end{array}$ & $\begin{array}{l}0 \\
0\end{array}$ & $\begin{array}{l}3.2 \\
0.7\end{array}$ & $\begin{array}{l}39.0 \\
8.7\end{array}$ & $\begin{array}{l}77.7 \\
17.3\end{array}$ & $\begin{array}{l}250.8 \\
56.0\end{array}$ & $\begin{array}{l}77.2 \\
17.2\end{array}$ & 447.9 \\
\hline $\begin{array}{c}13 \text { hectares } \\
\%\end{array}$ & $\begin{array}{l}0 \\
0\end{array}$ & $\begin{array}{l}2.1 \\
0.7\end{array}$ & $\begin{array}{l}64.6 \\
19.7\end{array}$ & $\begin{array}{l}70.3 \\
21.5\end{array}$ & $\begin{array}{l}110.9 \\
33.9\end{array}$ & $\begin{array}{l}79.1 \\
24.2\end{array}$ & 327.0 \\
\hline TOTAL & $\begin{array}{l}177.0 \\
4.6\end{array}$ & $\begin{array}{l}495.3 \\
12.7\end{array}$ & $\begin{array}{l}237.0 \\
6.1\end{array}$ & $\begin{array}{l}374.0 \\
9.6\end{array}$ & $\begin{array}{l}2104.8 \\
54.1\end{array}$ & $\begin{array}{l}499.6 \\
12.9\end{array}$ & 3887.7 \\
\hline
\end{tabular}

* developed - high $=$ commercial; low $=$ residential 
APPENDIX I. Summary of watershed land use areas for Corbin Creek Pond watershed by zone, with simulated BOTTOM development,in hectares.

\begin{tabular}{|c|c|c|c|c|c|c|c|}
\hline$\frac{\text { LANDUSE }}{\text { ZONE }}$ & $\mathrm{HIGH}^{*}$ & LOW* & GRASS & CROP & FOREST & $\begin{array}{l}\text { WETLAND } \\
\text { AREA }\end{array}$ & $\begin{array}{l}\text { TOTAL } \\
\text { AREA }\end{array}$ \\
\hline $\begin{array}{c}1 \text { hectares } \\
\%\end{array}$ & $\begin{array}{l}0 \\
0\end{array}$ & $\begin{array}{l}0.4 \\
0.2\end{array}$ & $\begin{array}{l}9.3 \\
3.9\end{array}$ & $\begin{array}{l}13.8 \\
5.8\end{array}$ & $\begin{array}{l}163.2 \\
68.0\end{array}$ & $\begin{array}{l}53.3 \\
22.2\end{array}$ & 240.0 \\
\hline $\begin{array}{c}2 \text { hectares } \\
\%\end{array}$ & $\begin{array}{l}0 \\
0\end{array}$ & $\begin{array}{l}0 \\
0\end{array}$ & $\begin{array}{l}0 \\
0\end{array}$ & $\begin{array}{l}0 \\
0\end{array}$ & $\begin{array}{l}183.5 \\
83.5\end{array}$ & $\begin{array}{l}36.3 \\
16.5\end{array}$ & 219.8 \\
\hline $\begin{array}{c}3 \text { hectares } \\
\%\end{array}$ & $\begin{array}{l}0 \\
0\end{array}$ & $\begin{array}{l}0 \\
0\end{array}$ & $\begin{array}{l}19.1 \\
13.2\end{array}$ & $\begin{array}{l}12.6 \\
8.7\end{array}$ & $\begin{array}{l}57.7 \\
39.9\end{array}$ & $\begin{array}{l}55.2 \\
38.2\end{array}$ & 144.6 \\
\hline $\begin{array}{c}4 \text { hectares } \\
\%\end{array}$ & $\begin{array}{l}0 \\
0 \\
\end{array}$ & $\begin{array}{l}0 \\
0 \\
\end{array}$ & $\begin{array}{l}2.3 \\
1.4 \\
\end{array}$ & $\begin{array}{l}0 \\
0\end{array}$ & $\begin{array}{l}116.1 \\
68.2 \\
\end{array}$ & $\begin{array}{l}51.8 \\
30.4 \\
\end{array}$ & 170.2 \\
\hline $\begin{array}{c}5 \text { hectares } \\
\%\end{array}$ & $\begin{array}{l}0 \\
0\end{array}$ & $\begin{array}{l}0 \\
0\end{array}$ & $\begin{array}{l}18.4 \\
10.8\end{array}$ & $\begin{array}{l}16.1 \\
9.4\end{array}$ & $\begin{array}{l}112.1 \\
65.7\end{array}$ & $\begin{array}{l}24.0 \\
14.1\end{array}$ & 170.6 \\
\hline $\begin{array}{c}6 \text { hectares } \\
\%\end{array}$ & $\begin{array}{l}0 \\
0\end{array}$ & $\begin{array}{l}0.1 \\
0\end{array}$ & $\begin{array}{l}3.1 \\
1.9\end{array}$ & $\begin{array}{l}29.6 \\
17.4\end{array}$ & $\begin{array}{l}107.1 \\
62.9\end{array}$ & $\begin{array}{l}30.3 \\
17.8\end{array}$ & 170.2 \\
\hline $\begin{array}{c}7 \text { hectares } \\
\%\end{array}$ & $\begin{array}{l}0 \\
0\end{array}$ & $\begin{array}{l}0.4 \\
0.1\end{array}$ & $\begin{array}{l}17.4 \\
5.9\end{array}$ & $\begin{array}{l}2.8 \\
1.0\end{array}$ & $\begin{array}{l}231.1 \\
78.9\end{array}$ & $\begin{array}{l}41.2 \\
14.1\end{array}$ & 292.8 \\
\hline $\begin{array}{c}8 \text { hectares } \\
\%\end{array}$ & $\begin{array}{l}0 \\
0 \\
\end{array}$ & $\begin{array}{l}0 \\
0\end{array}$ & $\begin{array}{l}32.3 \\
14.2 \\
\end{array}$ & $\begin{array}{l}46.7 \\
20.6\end{array}$ & $\begin{array}{l}118.3 \\
52.2\end{array}$ & $\begin{array}{l}29.5 \\
13.0\end{array}$ & 226.8 \\
\hline $\begin{array}{c}9 \text { hectares } \\
\%\end{array}$ & $\begin{array}{l}0.2 \\
0 \\
\end{array}$ & $\begin{array}{l}0.8 \\
1.0 \\
\end{array}$ & $\begin{array}{l}9.1 \\
1.6 \\
\end{array}$ & $\begin{array}{l}59.0 \\
10.2\end{array}$ & $\begin{array}{l}437.2 \\
75.6\end{array}$ & $\begin{array}{l}72.1 \\
12.5\end{array}$ & 578.4 \\
\hline $\begin{array}{c}10 \text { hectares } \\
\%\end{array}$ & $\begin{array}{l}52.2 \\
16.8\end{array}$ & $\begin{array}{l}197.8 \\
63.5\end{array}$ & $\begin{array}{l}9.1 \\
2.9\end{array}$ & $\begin{array}{l}36.1 \\
11.6\end{array}$ & $\begin{array}{l}16.2 \\
5.2\end{array}$ & $\begin{array}{l}0 \\
0\end{array}$ & 311.4 \\
\hline $\begin{array}{c}11 \text { hectares } \\
\%\end{array}$ & $\begin{array}{l}51.4 \\
8.7 \\
\end{array}$ & $\begin{array}{l}106.9 \\
18.2 \\
\end{array}$ & $\begin{array}{l}25.5 \\
4.3 \\
\end{array}$ & $\begin{array}{l}21.9 \\
3.7 \\
\end{array}$ & $\begin{array}{l}371.7 \\
63.2 \\
\end{array}$ & $\begin{array}{l}10.6 \\
1.8 \\
\end{array}$ & 588.0 \\
\hline $\begin{array}{c}12 \text { hectares } \\
\%\end{array}$ & $\begin{array}{l}73.2 \\
16.3 \\
\end{array}$ & $\begin{array}{l}186.8 \\
41.7 \\
\end{array}$ & $\begin{array}{l}26.8 \\
6.0 \\
\end{array}$ & $\begin{array}{l}65.1 \\
14.5 \\
\end{array}$ & $\begin{array}{l}79.8 \\
17.8 \\
\end{array}$ & $\begin{array}{l}16.2 \\
3.6 \\
\end{array}$ & 447.9 \\
\hline $\begin{array}{c}13 \text { hectares } \\
\%\end{array}$ & $\begin{array}{l}0 \\
0\end{array}$ & $\begin{array}{l}2.1 \\
0.6\end{array}$ & $\begin{array}{l}64.6 \\
19.8\end{array}$ & $\begin{array}{l}70.3 \\
21.5\end{array}$ & $\begin{array}{l}110.9 \\
33.9\end{array}$ & $\begin{array}{l}79.1 \\
24.2\end{array}$ & 327.0 \\
\hline TOTAL & $\begin{array}{l}177.0 \\
4.6\end{array}$ & $\begin{array}{l}495.3 \\
12.7\end{array}$ & $\begin{array}{l}237.0 \\
6.1\end{array}$ & $\begin{array}{l}374.0 \\
9.6\end{array}$ & $\begin{array}{l}2104.8 \\
54.1\end{array}$ & $\begin{array}{l}499.6 \\
12.9\end{array}$ & 3887.7 \\
\hline
\end{tabular}

* developed - high $=$ commercial; low $=$ residential 


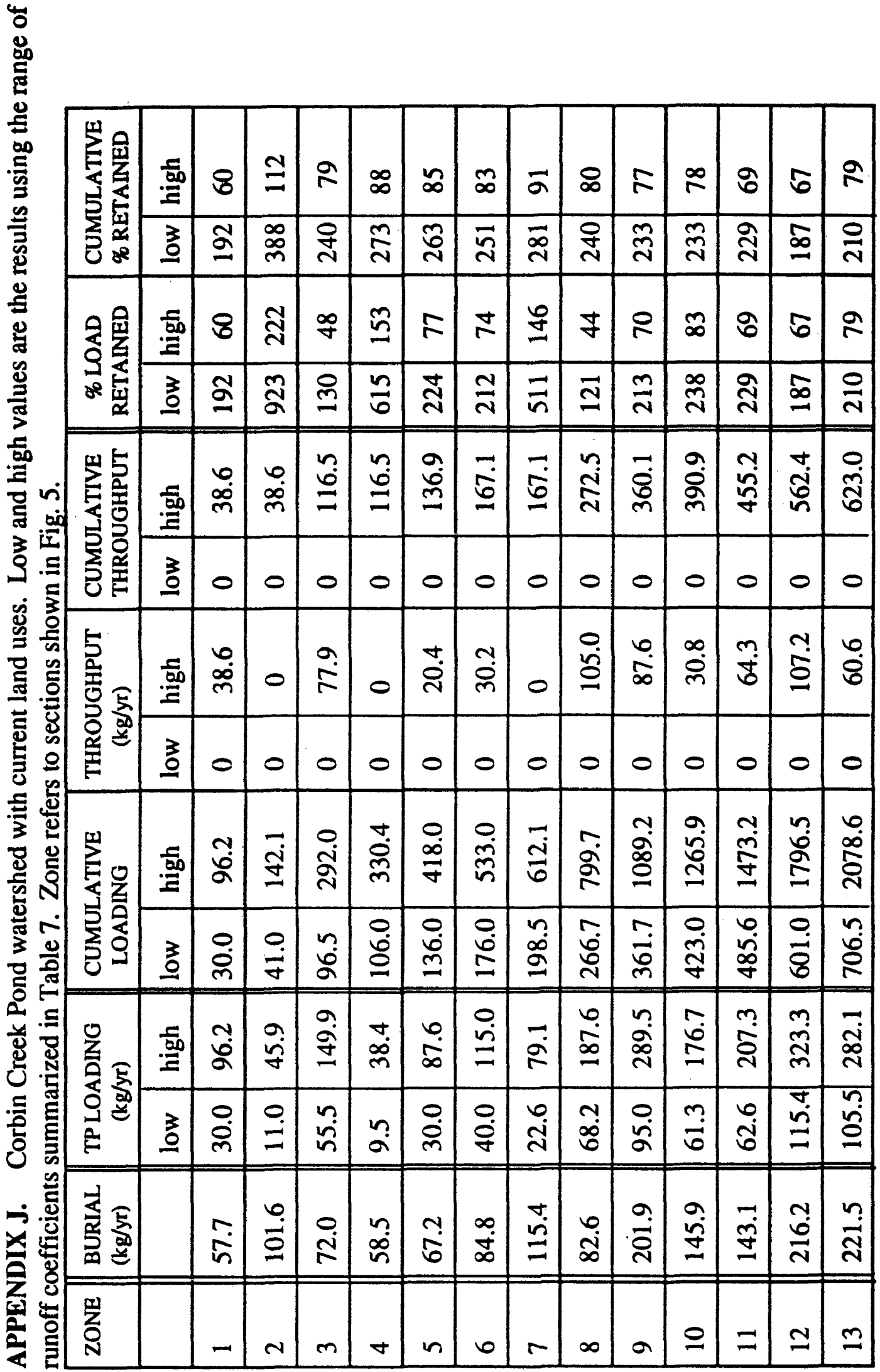




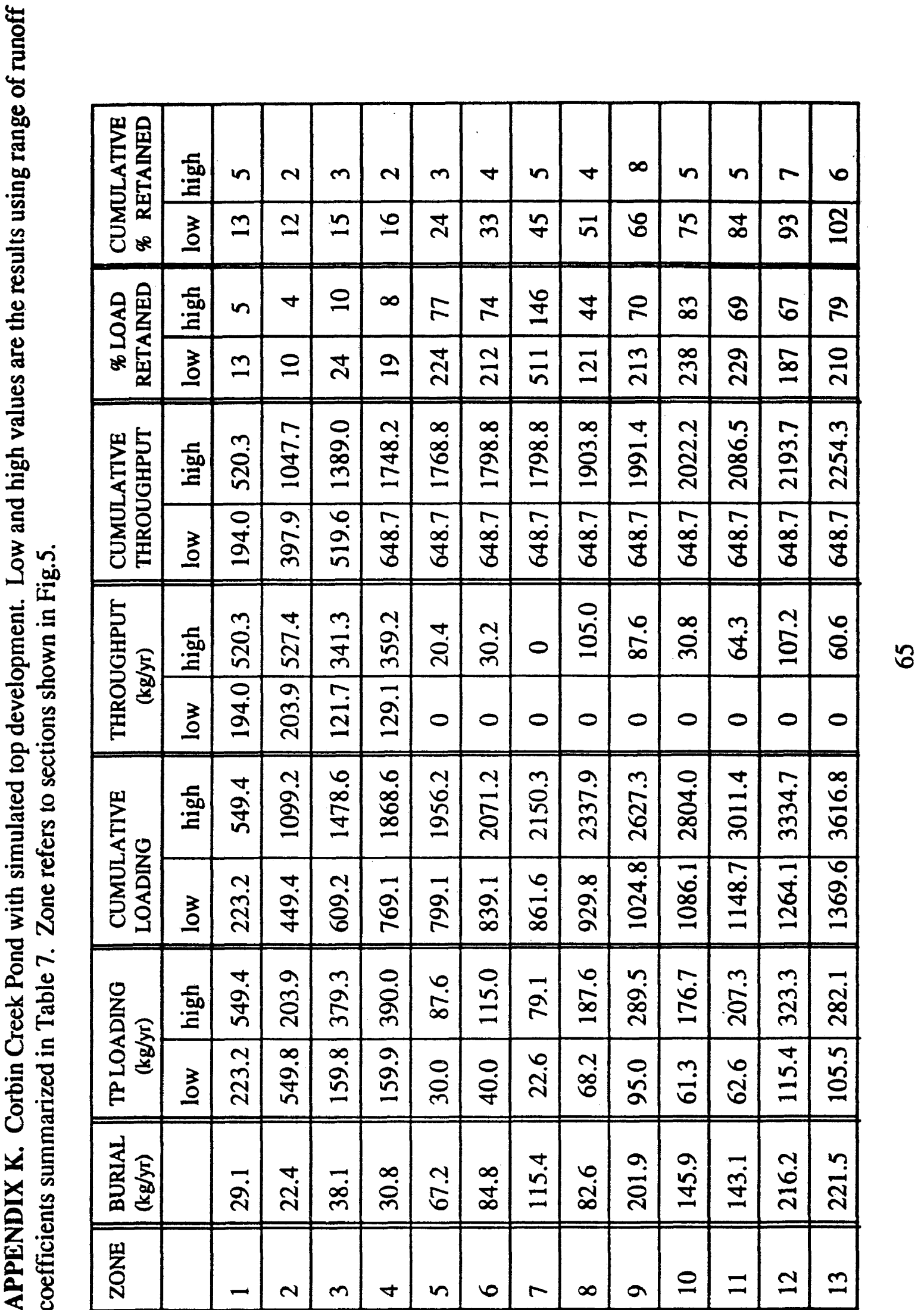




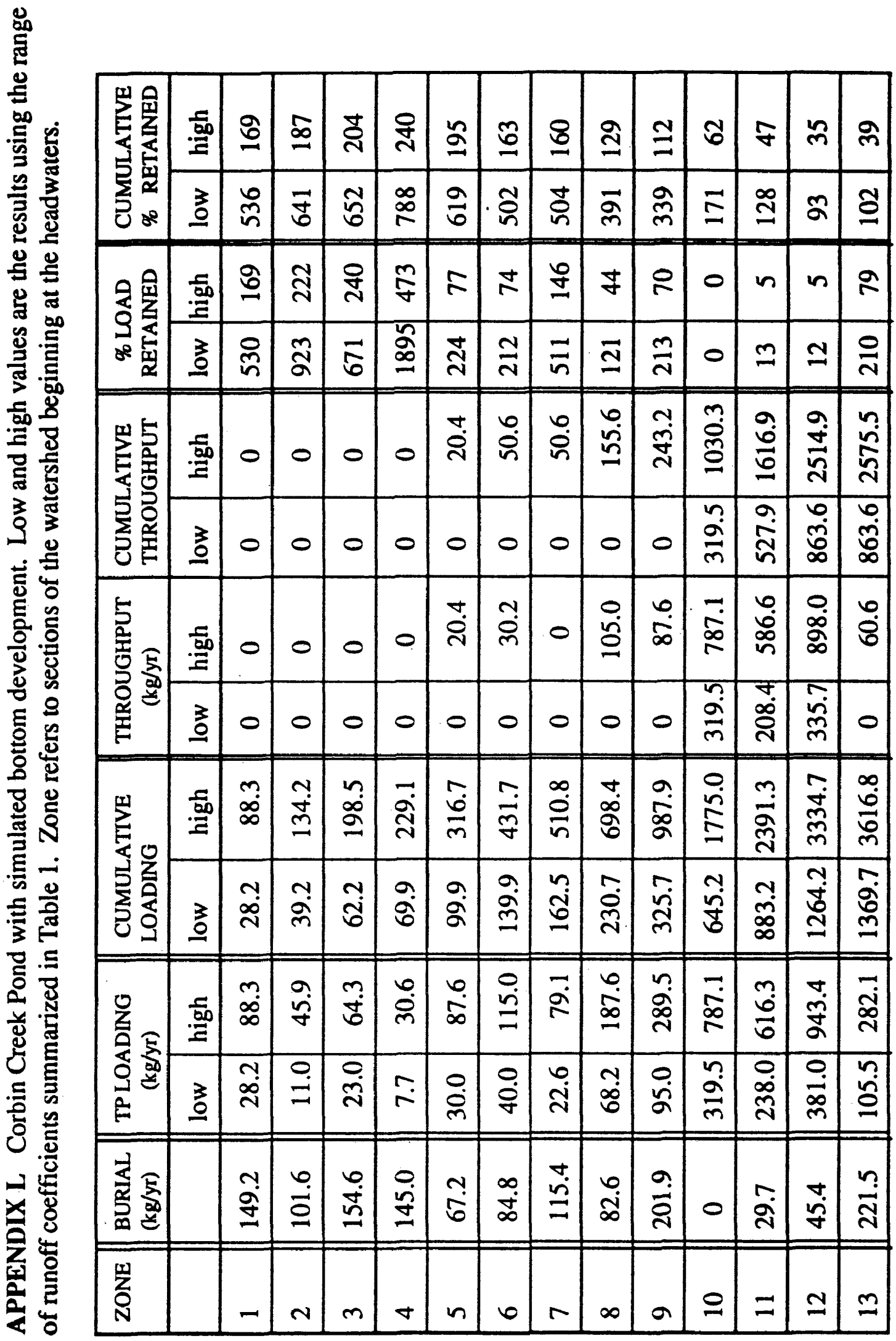




\section{LITERATURE CITED}

Allen, S.E., H.M. Grimshaw, J.A. Parkinson and C. Quarmby. 1974. Chemical Analysis of Ecological Materials. John Wiley \& Sons. NY.

Anderson, G.F. and C. Bosco. 1981. Nonpoint sources and impacts in a small coastal plain estuary. pp.53-63. in K.Flynn ed. Nonpoint pollution control tools and techniques for the future. Interstate Commission of the Potomac River Basin.

Aspila, K., H. Agemian and A. Chau. 1976. A semi-automated method for the determination of inorganic, organic and total phosphate in sediments. Analyst 101:187-197.

Bannerman, R., K.Baun, M. Bohm, P.E. Hughes and D.A. Graczyk. 1984. Evaluation of Urban Nonpoint Source Pollution Management in Milwaukee County, Wisconsin. Report No. PB84-114164. Chicago, Ill. EPA Region V.

Beulac, M.N. and K.H. Reckhow. 1982. An examination of landuse nutrient export relationships. Water Resources Bulletin. 18:1013-1023.

Brickman, E. 1978. ${ }^{137} \mathrm{Cs}$ Chronology in Marsh and Lake Samples from Delaware. Univ. of Delaware thesis.

Carter, L.W., R.C. Knox and D.M. Fairchild. 1987. Groundwater Quality Protection. Lewis Publ. MI.

Correll, D.L. 1977. Relationship of Land Use to Water Quality in the Chesapeake Bay Region.

Cowardin, L.M., V. Carter, F.C. Golet and E.T. LaRoe. 1979. Classification of Wetlands and Deepwater Habitats in the United States. U.S. Fish and Wildlife Service Pub. FWS/OBS -79/31. Washington, D.C.

Craft, C.B. and C.J. Richardson. 1993. Peat Accretion and N, P and organic C accumulation in nutrient enriched and unenriched everglades peatlands. Ecological Applications 3:446-458.

DeLaune, R.D., R.H. Baumann and Gosselink, J.G. 1983. Relationships among vertical accretion, coastal submergence, and erosion in a Louisiana Gulf Coast marsh. J.Sediment.Pet. 53:147-157.

DeLaune, R.D., J.H. Whitcomb, W.H. Patrick, Jr. and S.R. Pezeshki. 1989. Accretion and Canal Impacts in a Rapidly Subsiding Wetland. I. ${ }^{137} \mathrm{Cs}$ and ${ }^{210} \mathrm{~Pb}$ Techniques. Estuaries 12: 247-259. 
Detenbeck, N.E., C.A. Johnston and G.J. Niemi. 1993. Wetland effects on lake water quality in the Minneapolis/St. Paul metropolitan area. Landscape Ecology 8:39-61.

ERDAS, Inc. 1994. ERDAS Field Guide. Third Edition. Atlanta, GA.

ESRI, 1992. Arc/Info Users Guide. USA.

Folk, R.I. 1980. Petrology of Sedimentary Rocks. Hemphill Publ. Co. TX.

Golley, F.B. 1988. Introducing landscape ecology. Landscape Ecology 1(1):1-3.

Grobler, D. and M. Silberbauer. 1985. The combined effect of geology, phosphate sources and run off on phosphate export from drainage basins. Water Res. 19:975-981.

Hatton, R.S., R.D. DeLaune and W.H. Patrick Jr. 1983. Sedimentation, accretion, and subsidence in marhes of Barataris Bsin, Louisiana. Limnol. Oceanogr. 28:494502.

Hammer, M.J. 1986. Water and Wastewater Technology. John Wiley \& Sons. NY.

Heliotis, F.D. and C.B. De Witt. 1983. A conceptual model of nutrient cycling in wetlands used for wastewater treatment: a literature analysis. Wetlands 3:134152.

Johnston, C.A. G.D. Burbenzer, G.B. Lee, F.W. Madison and J. MacHenry. 1984. Nutrient trapping by sediment deposition in a seasonally flooded lakeside wetland. J. Env.Quality 13:283-290.

Jones, R. and B.Holmes. 1985 Effects of Land Use Practices on Water Resources in Virginia. Virginia Water Resources Research Center Bulletin 144.

Kearny, M.S., J.P. Leatherman and G.T.F. Wong. 1983. Recent accretion rates at Blackwater Wildlife Refuge. Univ. of MD. Water Resources Research Center. TR78.

Khan, H. and G. Brush. 1994. Nutrient and Metal Accumulation in a Freshwater Tidal Marsh. Estuaries 17:345-360.

Likens, G.E., F.H. Buamann, R.S. Pierce, J.S. Eaton and N.M. Hohnson. 1977. Biogeochemistry of a Forested Ecosystem. Springer-Verlag NY. 
Loehr, R.C. 1974. Characteristics and comparative magnitude of non-point sources. Journal WPCF 46:1849-1872.

Mackieman, G. 1985. Sources and Impact of Nutrients in Chesapeake Bay in: C.W. Coale ed. Proc. of Conference on Land Use and the Chesapeake Bay. Dec. 1985.

Marsalek, J. 1978. Pollution Due to Urban Runoff: Unit Loads and Abatement Measures. Windsor, Ontario, Canada: Pollution by Lnad Use Activities Reference Group of the International Joint Commision.

McIntyre, S.C. and J.W. Naney. 1991. Sediment deposition in a forested inland wetland with a steep-farmed watershed. J.Soil Water Conservation. 46:64-66.

Mitsch, W.J. and J.G. Gosselink. 1993. Wetlands. Van Nostrand Reinhold. NY.

Mitsch, W., C. Dorge and J. Wiemhoff. 1979. Ecosystem dynamics in four seasonally flooded forest communities of the Dismal Swamp. Amer. J. of Botany. 75:13341343.

Nichols, D.S. 1983. Capacity of natural wetlands to remove nutrients from wastewater. J.Water Pollution Control Federation. 55:495-505.

Nixon, S.W. 1980. Between coastal marshes and coastal waters: A review of 20 years of speculation and research on the role of salt marshes in estuarine productivity and water chemistry. pp. 438-525. In P.Hamilton and K. MacDonald ed. Estuarine and Wetland Processes. Plenum Press. NY.

Oertel, G., G. Wong and J. Conway. 1989. Sediment accumulation at a fringe marsh during transgression, Oyster, VA. Estuaries 12:18-26.

Orson et al. 1985. Response of tidal salt marshes of the US Atlantic and Gulf coasts to rising sea levels. J. of Coastal Research 1:29-37.

Pennington, W., R.S. Cambrey and E.M. Fisher. 1973. Observations on lake sediments using shallow ${ }^{137} \mathrm{Cs}$ as a tracer. Nature 242:324-326.

Peterjohn, W.T. and D.L. Correll. 1984. Nutrient Dynamics in an Agricultural Watershed: Observations on the role of a Riparian Forest. Ecology 65:1466-1475.

Rast, W. and G. Lee. 1983. Nutrient Loading Estimates for Lakes. J. Env. Eng. ASCE 109:502-517.

Reed, D.J. and D.R. Stoddart. 1989. Sedimentation and accretion. in D.R. Stoddart ed. Salt Marshes,Morphology, Process and Management. Basil Blackwell. 
Reed, D.J. 1987. Short-term variability in salt marsh sedimentation, Terrebonne Bay, Louisiana. pp.221-234 in N.V. Brodtmann ed. Proc. Fourth Water Quality and Wetland Management Conference. Louisiana.

Richard, G.A. 1978. Seasonal and environmental variations in sediment accretion in a Long Island salt marsh. Estuaries. 1:29-35.

Richards, I.J. 1934. The salt marshes of Dovey Estuary IV. The rates of vertical accretion, horizontal extenison and scarp erosion. Ann. Bot. 48:225-259.

Richardson, C. 1985. Mechanisms controlling phosphorus retention capacity in freshwater wetlands. Science 228:1424-1427.

Richardson, C.J. and P.E. Marshal. 1986. Processes controlling movement, storage and export of phosphorus in a fen peatland. Ecol. Mong. 56:279-302.

Risser, P.G. Landscape ecology: State of the art. 1987. pp. 3-14 in M.G. Turner ed. Landscape Heterogeneity and Disturbance. Springer-Verlag, NY.

SAS Institute Inc. 1985. SAS User's Guide:Statistics. Version 5 Edition. Cary N.C.

Schueler, T.R. and M.R. Bley. 1987.A Framework for Evaluating Compliance with the 10\% Rule in the Chesapeake Bay Critical Area. Metropolitan Washington Council of Governments.

Simpson, R., R. Good, M. Leck and D.Whigham. 1983. The ecology of freshwater tidal wetlands. Bioscience 33:255-259.

Sonzogni, W., G. Chesters, D. Coote, D. Jeffs, J. Konrad, R. Ostry, J. Robinson. 1980. Pollution from land runoff. Env. Sci. \& Tech. 14:148-153.

Spangler, F.L., C.W. Fetter, Jr. and W.E. Sloey. 1977. Phosphorus AccumulationDischarge Cycles in Marshes. Water Resources Bull. 13:1191-1201.

Steers, J.A. 1938. The rate of sedimentation of salt marshes on Scolt Head Island Norfolk. Geol. Mag. 75:26-39.

Steers, J.A. 1948. Twelve years measurement of accretion in Norfolk salt marshes. Geol. Mag. 85:163-166.

Stevenson, C.L., L.G. Ward and M.S. Kearny. 1986. Vertical accretion in marshes with varying rates of sea level rise in D.A. Wolfe ed. Estuarine Variablity. Academic Press. NY. 
Stoddart, David R., D.J. Reed and J.R. French. 1989. Understanding Salt-Marsh Accretion, Scolt Head Island, Norfolk, England. Estuaries 12:228- 236.

Thom, R.M. 1992. Accretion rates of low intertidal salt marshes in the Pacific Northwest. Wetlands 12:147-156.

Tilton, D.L. and R.H. Kadlec. 1979. The Utilization of Fresh-Water Wetland for Nutrient Removal from Secondarily Treated Waste Water Effluent. J.Environ. Qual. 8:328-334.

Tumer, Monica G. 1990. Spatial and temporal analysis of landscape patterns. Landscape Ecology 4:21-30.

United States Environmental Protection Agency. 1983. Results of the Nationwide Urban Runoff Program: Volume 1. USEPA, Washington, D.C.

United States Department of Commerce, NOAA, and National Ocean Service. 1985. National Estuarine Inventory. Data Atlas. V.1: Physical and Hydrologic Characteristics.

Uttormark, P. , J. Chapin and K. Green. 1974. Estimating Nutrient Loading of Lakes from Non-point Sources. US EPA. EPA-660/12-74-020.

van der Leeden, Frits. 1993. Water Atlas of Virginia: Basic Facts about Virginia's Water Resources. Tennyson, VA..

Virginia Department of Environmental Quality. 1984-1994. Chesapeake Bay Tributary Monitoring Data.

Walker, W. 1987. Phosphorus removal by urban runoff detention basins. Lake and Reservoir Management 3:314-326.

Wanielista, M.P. 1978 Stormwater Management: Quantity and Quality. Ann Arbor Science Publishers.

Warinner, J.E. 1962. Adsorption of Radionuclides in Clay Minerals. VIMS Thesis.

Whigham, D.F. and S.E. Bayley. 1979. Nutrient Dynamics in freshwater wetlands. in P.E. Greeson, J.R.Clark and J.E Clark. eds. American Water Res. Assoc. MN.

Whipple, W. Jr. J.V. Hunter, and S.L. Yu. 1978. Runoff pollution from multiple family housing. Water Res. Bull. 14:288-301. 
Wiens, J.A. and B.T. Milne. 1989. Scaling of 'landscapes' in landscape ecology, or, landscape ecology from a beetle's perspective. Landscape Ecol. 3:87-96.

Wilcox, J. 1989. Recent Vegetation and Area Changes in a Tidal Marsh located at Pope's Creek, VA. VIMS Thesis.

Wood, M. , J. Kelley and D. Belknap. 1989. Patterns of sediment accumulation in the tidal marshes of Maine. Estuaries 12:237-246.

Yarbro, L.A. 1983. The influence of hydrologic variations on phophorus cycling and retention in a swamp stream ecosystem. in T. Fontaine amd S. Bartell ed. Dynamics of Lotic Ecosystems. Ann Arbor, MI. 